\title{
The role of magma mixing and mafic recharge in the evolution of a back-arc quaternary caldera: The case of Payún Matrú, Western Argentina
}

\author{
Irene Raquel Hernando ${ }^{\mathrm{a}, *}$, Ivan Alejandro Petrinovic ${ }^{\mathrm{b}}$, Eduardo Jorge Llambías ${ }^{\text {a }}$, Leandro D'Elia ${ }^{\mathrm{a}}$, \\ Pablo Diego González ${ }^{\text {c }}$, Eugenio Aragón ${ }^{\text {a }}$ \\ a Centro de Investigaciones Geológicas (CONICET - Universidad Nacional de La Plata), Diagonal 113 N²75, B1904DPK, La Plata, Argentina \\ b Centro de Investigaciones en Ciencias de la Tierra (Universidad Nacional de Córdoba - CONICET), Av. Vélez Sarfield 1611, X5016GCA Córdoba, Argentina \\ c Instituto de Investigación en Paleobiología y Geología (Universidad Nacional de Río Negro - CONICET), Av. J.A. Roca 1242, 8332 General Roca, Argentina
}

\section{A R T I C L E I N F O}

Article history:

Received 1 September 2015

Accepted 15 January 2016

Available online 26 January 2016

Keywords:

Payún Matrú caldera

Trachytes

Magma mixing

Eruption trigger

\begin{abstract}
A B S T R A C T
The Quaternary Payún Matrú volcano is a long-lived edifice that developed a summit caldera 8 km wide, with abundant pre- and post-caldera volcanic activity. It is the main volcano of the Payún Matrú Volcanic Field, which is located in the back-arc Payenia Basaltic Province, at mid-western Argentina. The composition of Payún Matrú is mainly trachytic, with lesser amounts of trachyandesitic and basaltic trachyandesitic lavas. The Payún Matrú Volcanic Field includes also the Payún Liso stratovolcano and more than 200 monogenetic basaltic cones and associated lava flows that are located east and west of the caldera. The aim of this work is to show the Payún Matrú evolution based on the mineralogical and textural characterization and to make inferences on the trigger mechanism for the explosive eruption which leads to the caldera formation. Some intermediate lavas and trachytes include phenocrysts with contrasting textures and composition, such as inverse zoning in plagioclase and clinopyroxenes, sieved plagioclases with a more calcic rim and calcic plagioclases with a more sodic rim, indicating that they could not have formed together and suggesting magma mixing processes. In addition, a few lavas show mafic enclaves or texturally different groundmasses with fluidal contacts, indicating mingling between two magmas. These lavas are found in the pre-caldera stage and the early post-caldera stage of Payún Matrú. The trachytic pyroclastic deposits related to the caldera collapse do not exhibit evidence of hybridization, although they present a minor proportion of dissolved feldspars and biotite replaced by anhydrous minerals, suggesting that a restricted zone of the chamber was reheated. This may be explained by a mafic recharge event where part of the host trachytic magma was heated, but without a complete homogenization between the host and recharging magmas. These features, in addition to the abundant basaltic volcanism east and west of the caldera, suggest that the trigger mechanism for the explosive eruption was the injection of basaltic magma into the trachytic chamber of Payún Matrú.
\end{abstract}

(c) 2016 Elsevier B.V. All rights reserved.

\section{Introduction}

The Payún Matrú Volcanic Field $\left(36^{\circ} 25^{\prime} \mathrm{S}, 69^{\circ} 10^{\prime} \mathrm{W}\right)$ is located within the Payenia Basaltic Province, in the Andean back-arc of the Southern Volcanic Zone, western Argentina (Fig. 1). It is one of the six volcanic fields of Payenia, along with the Llancanelo, Nevado, and Río Colorado volcanic fields and dispersed volcanic vents in the retroarc zone and northern Payenia (Gudnason et al., 2012). The Payún Matrú Volcanic Field (PMVF) is Pleistocene-Holocene (Germa et al., 2010; Gudnason et al., 2012; Hernando et al., 2014a; Espanon et al., 2014a; Marchetti et al., 2014), and it is constituted by the Payún Matrú volcano,

\footnotetext{
* Corresponding author. Tel.: +542216441269.

E-mail address: ihernando@cig.museo.unlp.edu.ar (I.R. Hernando).
}

Payún Liso stratovolcano and more than 200 monogenetic basaltic cones with associated lava flows (Fig. 2a; Llambías, 1966; Inbar and Risso, 2001; Hernando et al., 2012, 2014b). Within the PMVF, the Payún Matrú volcano is the main edifice, it is mainly trachytic in composition and presents a summit caldera $8 \mathrm{~km}$ wide. The basaltic and trachytic volcanism in PMVF are contemporaneous, as indicated by stratigraphic relations and radiogenic ages (Germa et al., 2010; Gudnason et al., 2012; Hernando et al., 2012, 2014a; Espanon et al., 2014a). The basaltic volcanic vents are distributed in a relatively narrow fringe located east and west of Payún Matrú, and they are interrupted in the middle zone where the polygenetic volcano is situated (Llambías, 1966; Hernando et al., 2012, 2014b). The absence of basalts in the Payún Matrú volcano suggest that basaltic magmas interacted with the trachytic magma chamber on their way to the surface. Textural, 


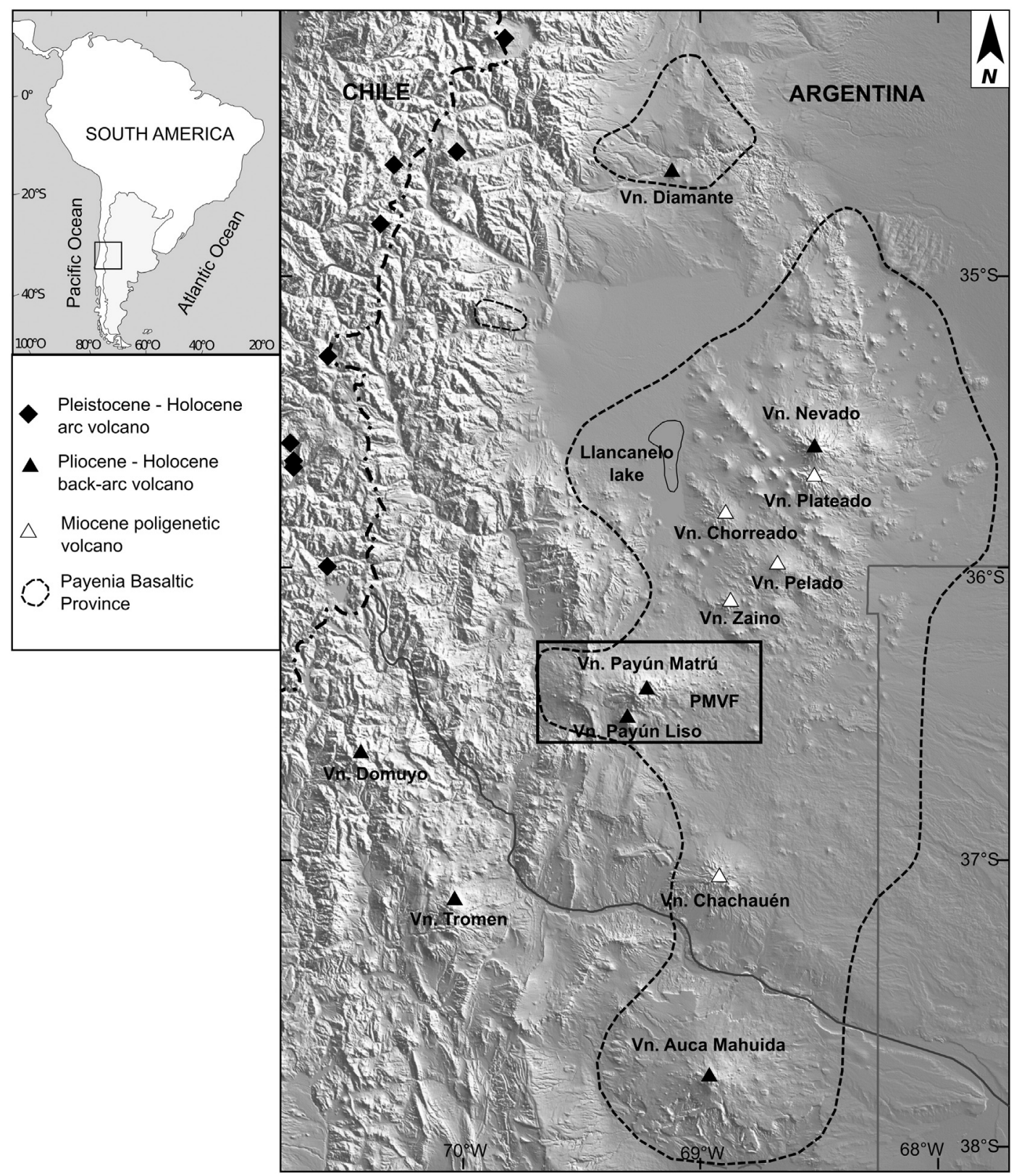

Fig. 1. Location of the Payún Matrú Volcanic Field (PMVF) within the Payenia Basaltic Province, in the Andean retro-arc of western Argentina.

mineralogical, and chemical evidence of magma mixing and mingling between mafic and silicic magmas are recurrently found in Payún Matrú volcanic rocks (Hernando et al., 2012, 2014a).

The aim of this work is to determine the evolution of the magmatic system that formed the Payún Matrú caldera based on the mineralogical and textural characterization of the PMVF rocks, and to provide an explanation for magma mixing and mingling processes as well as the trigger mechanism for the explosive eruption which lead to the Payún Matrú caldera formation.

\section{Geological setting}

Payenia $\left(34^{\circ}-38^{\circ} \mathrm{S}\right)$ extends from the easternmost zone of the Andean cordillera to the back-arc area, around $500 \mathrm{~km}$ from the trench, overlying rocks of the San Rafael Block (Fig. 1). This basaltic province is represented mostly by alkaline basalts with an intraplate to weakly arc affinity, along with relatively few polygenetic volcanoes of intermediate to acid composition (Bermúdez and Delpino, 1989; Bermúdez et al., 1993; Kay et al., 2006, 2013; Llambías et al., 2010; Hernando et al., 2012; Søager et al., 2013; Espanon et al., 2014b). The alkaline volcanism in Payenia followed a period of arc volcanism in the back-arc area in Miocene times, beginning in late Pliocene, at ca. 3 Ma to Holocene (Kay et al., 2006; Folguera et al., 2009; Quidelleur et al., 2009; Germa et al., 2010; Gudnason et al., 2012; Espanon et al., 2014a; Marchetti et al., 2014). The most recent Holocene activity is registered in the PMVF, with basaltic lavas around 2 ka old (Marchetti et al., 2014; Espanon et al., 2014a).

The mantle source of Payenia basalts is heterogeneous and differs from northern Payenia to southern Payenia, as indicated by chemical and isotopic data (Søager et al., 2013, 2015). The northern Payenia basaltic melts have been influenced by subduction zone components and lower crustal contamination, while southern Payenia (where the PMVF is located) has an OIB-like mantle source without slab components (Søager et al., 2013, 2015; Hernando et al., 2014a). 


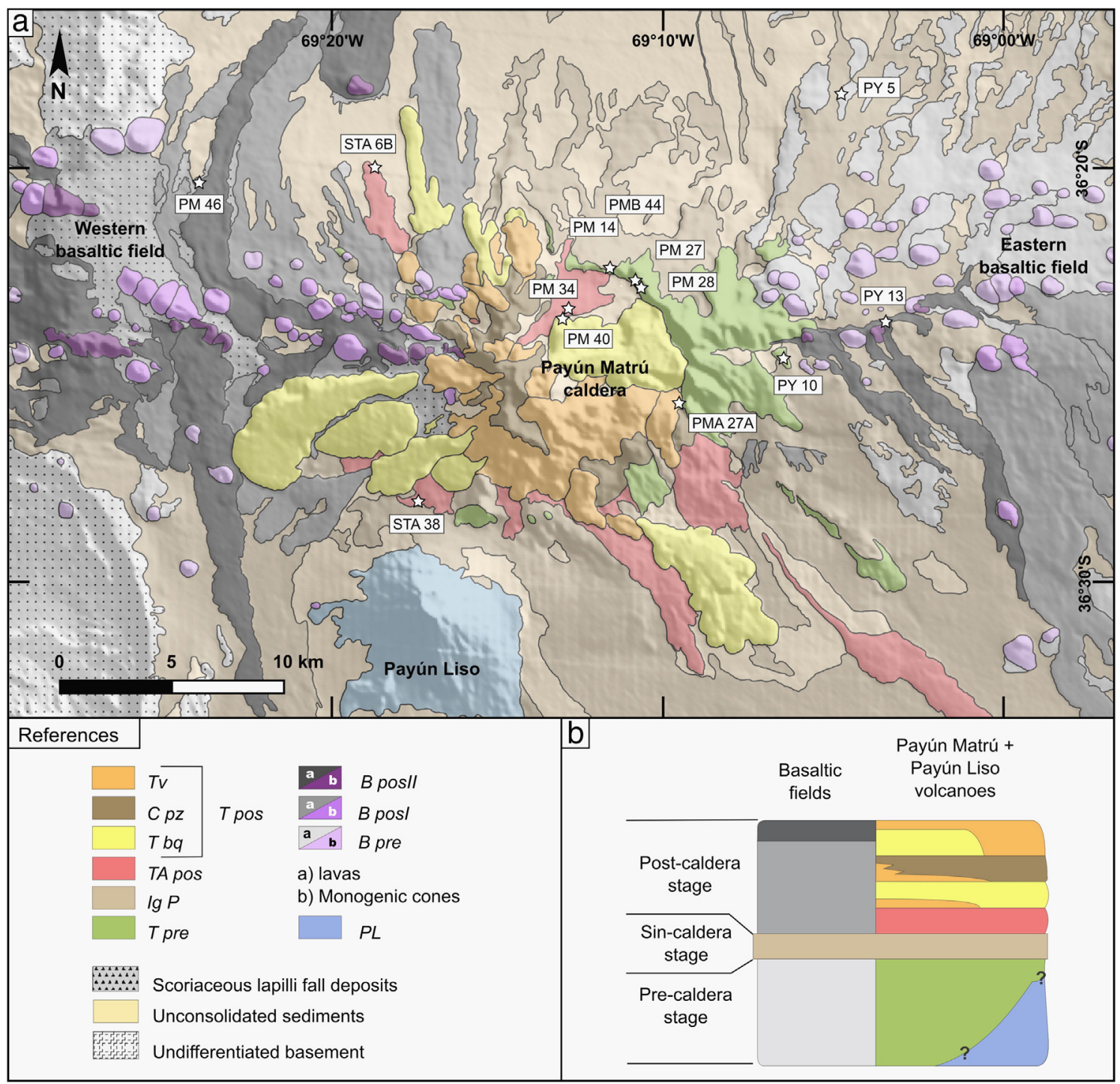

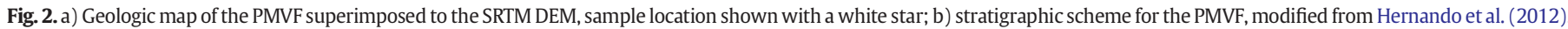

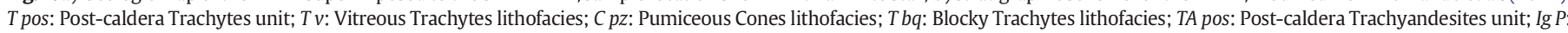
Portezuelo Ignimbrite; $T$ pre: Pre-caldera Trachytes unit; B posII: Post-caldera Basalts II unit; B posI: Post-caldera Basalts I unit; $B$ pre: Pre-caldera Basalts unit; PL: Payún Liso volcano.

\subsection{Eruptive history of PMVF}

The Payún Matrú volcano is a multi-vent shield-shaped edifice with a basal diameter of about $15 \mathrm{~km}$ (Fig. 2a). The volcanic activity in the basaltic fields within the PMVF, Payún Matrú, and Payún Liso was synchronous according to primary stratigraphic relationships of volcanic lavas and deposits and radiometric ages (Germa et al., 2010; Gudnason et al., 2012; Hernando et al., 2012, 2014a; Espanon et al., 2014a; Marchetti et al., 2014). The development of the Payún Matrú caldera in late Pleistocene produced a widespread ignimbrite, which can be used as a stratigraphic marker and allows the subdivision of the PMVF volcanism into pre-caldera, syn-caldera, and post-caldera stages (Hernando et al., 2012). A stratigraphic scheme is shown in Fig. 2 b.

\subsubsection{Pre-caldera stage}

The pre-caldera stage of the PMVF is the most extended, lasting at least about $600 \mathrm{ka}$. The oldest dated lava of the Payún Matrú volcano is a trachyte of $700 \mathrm{ka}$ (Hernando et al., 2014a). This stage remained until the eruption of the Portezuelo Ignimbrite, around $100 \mathrm{ka}$ ago (between 148 ka and 82 ka; Germa et al., 2010; Hernando et al., 2014a). The volcanic products of the pre-caldera stage of Payún Matrú volcano are grouped in the Pre-caldera Trachytes unit (T pre), composed mostly of lava flows and domes, along with minor proportions of welded ignimbrites, dykes, and volcaniclastic rocks (Hernando et al., 2012; Fig. 2). The composition of lavas is mostly trachytic, with lesser amounts of trachyandesites and basaltic trachyandesites (Hernando et al., 2014a). This unit crops out mostly in the northern to southeastern flank and caldera scarps of the volcano, where the collapse structure is exposed and where no post-caldera eruptions took place (Fig. 2a). The pre-caldera basaltic volcanism (Pre-caldera Basalts unit; $B$ pre) is widely exposed in the eastern basaltic field, with lesser representation on the western side of Payún Matrú, due to the widespread post-caldera activity in that zone (Fig. 2). The rocks of this unit correspond to basalts and trachybasalts (Hernando et al., 2014a).

\subsubsection{Syn-caldera stage}

The Payún Matrú caldera is approximately circular in shape, with a diameter of $8 \mathrm{~km}$. The north to southeast rim of the caldera has an interior scarp with a maximum height of $480 \mathrm{~m}$ above the caldera floor (Fig. 2a). The maximum subsidence cannot be determined, since the inner zone of the caldera is fully covered with post-caldera volcanic activity and modern sediments and, in addition, there is no information 
available of the syn-caldera deposits inside the caldera. The southern and western boundary of the caldera is defined by vent alignments of trachytic domes, coulees, and lava flows (Hernando et al., 2014b).

The pyroclastic deposits associated with the late Pleistocene Payún Matrú caldera formation are referred to the Portezuelo Ignimbrite (Ig P; Llambías, 1966). Its composition is trachytic and crops out radially from the caldera boundary, specially north and south of it, because younger lavas of the post-caldera activity do not cover it in this zone (Hernando et al., 2012, 2014a). The estimated volume is between 25 and $33 \mathrm{~km}^{3}$ (Germa et al., 2010; Llambías et al., 2010, respectively). The exact volume is not determined resulting from the lack of information about the intra-caldera ignimbrite, because the interior of the caldera is covered by later volcanic activity and sedimentation. Another factor is the highly variable thickness of the extra-caldera ignimbrite and the abundance of post-caldera volcanism that covers it, which makes it difficult to measure thicknesses of the syn-caldera deposits.

\subsubsection{Post-caldera stage}

The post-caldera volcanism in Payún Matrú is widespread in the southeastern to northern caldera margin (Fig. 2a), with relatively few lavas related to vents located in the middle to lower flank of the volcano (Hernando et al., 2014b). The first lavas erupted in this stage are represented by the Post-caldera Trachyandesites unit (TA pos; Hernando et al., 2012), composed of eight lava flows. The radiometric age available for this unit corresponds to the only flow inside the caldera, dated in $82 \mathrm{ka}$ (Germa et al., 2010). The latest eruptions of the Payún Matrú volcano are trachytic and relatively homogeneous in composition (Postcaldera Trachytes unit, T pos; Hernando et al., 2012, 2014a). The volcanic products record effusive and low explosivity eruptive behavior. They are represented by eight blocky lava flows (Blocky Trachytes lithofacies, $T \mathrm{bq}$ ), abundant vitrophyric domes, couleés and lava flows (Vitreous Trachytes lithofacies, $T v$ ), and several pumiceous cones (Pumiceous Cones lithofacies, $C p z$; Hernando et al., 2012). These three lithofacies are coeval, as indicated by field relationships and $\mathrm{Ar}-\mathrm{Ar}$ ages (37 ka for one pumiceous cone; $26 \mathrm{ka}, 15 \mathrm{ka}$, and $<7$ ka for three blocky trachytic lavas; and 20 ka for one vitrophyric lava; Germa et al., 2010; Hernando et al., 2014a). The volcanic activity during the post-caldera stage in the basaltic fields (Post-caldera Basalts I and II units; B posI and $B$ posII) occurred mostly in the western basaltic field, with the latest eruptions being Holocene, as indicated by cosmogenic ages (Espanon et al., 2014a; Marchetti et al., 2014). The rocks of these units are trachybasalts with lesser representation of basalts (Hernando et al., 2014a).

\section{Materials and methods}

Thirteen samples of the PMVF were selected for mineral analysis from both the basaltic fields and the Payún Matrú volcano. The samples analyzed are fresh, with no significant petrographic or whole-rock chemical evidence of alteration ( $\mathrm{LOI}<0.42 \%$ ). Minor alteration is present in a few cases but is limited to iddingsite staining olivine phenocrysts.

Chemical microanalyses of minerals were performed at the Geosciences Institute of the São Paulo University (Brazil), using a JEOL-SUPERPROBE JXA-8600 S microprobe. Operating conditions of the microprobe were $15 \mathrm{kV}$ of accelerating voltage, a sample current of $20.10 \pm 10 \mathrm{nA}, 10 \mu \mathrm{m}$ electron beam (for feldspars and glass), and $5 \mu \mathrm{m}$ electron beam (for mafic minerals). The count integration times were between 5 and $20 \mathrm{~s}$. Na and $\mathrm{K}$ were counted first for $5 \mathrm{~s}$ to minimize loss by volatilization, and then all the other elements were counted for at least $20 \mathrm{~s}$. The matrix-effect corrections were made (atomic number, mass absorption, and secondary fluorescence) with PROZA procedure (Bastin and Heijligers, 1990). Natural and artificial oxides and minerals were used as standards for all the minerals ( $\mathrm{Si}, \mathrm{Ca}$ : wollastonite; $\mathrm{Al}$ : anortite; Ti: routile; $\mathrm{Cr}$ : chromium oxide; $\mathrm{Mg}$ : diopside; Mn, Fe: olivine; Na: albite; K: asbesto; Sr: strontium silicate
SRAN; Ba: natural barium silicate; among others). The standards used for glass analyses were NIST glasses: VG56B (rhyolite) and VGA99 (basalt). Counting times for glass analyses were from $5 \mathrm{~s}(\mathrm{Si}, \mathrm{Al}, \mathrm{F})$ to $10 \mathrm{~s}$ (Fe, $\mathrm{Mn}, \mathrm{Ti}, \mathrm{Ca}, \mathrm{Mg}, \mathrm{Na}, \mathrm{K}$, and $\mathrm{Cl}$ ). Si, $\mathrm{Na}, \mathrm{K}, \mathrm{Cl}$, and Fe were read first, followed by $\mathrm{F}, \mathrm{Al}, \mathrm{Cl}$, and $\mathrm{Ti}$ and then $\mathrm{Mg}$.

The samples chosen for the analysis of mineral compositions are shown in Fig. 2a and Table 1. In the case of the Pre-caldera Trachytes unit, mineral compositions of one dyke exposed in the caldera wall and two lavas were analyzed. These three samples (PM 27, PM 28, PY 10) show textural evidence of disequilibrium, with sieved and nonsieved plagioclases, in addition to the presence of two different pilotaxitic groundmasses with a fluidal contact in sample PM 28. Two samples of the extra-caldera Portezuelo Ignimbrite were analyzed: one sample of a welded zone and another of juvenile trachytic spatter clasts. In the case of the Post-caldera Trachyandesites unit, mineral compositions of three lava flows were analyzed, and these lavas also show textural evidence of disequilibrium. Regarding the Post-caldera Trachytes unit, one sample of the Blocky Trachytes lithofacies, and another of the Vitreous Trachytes lithofacies were selected. Volcanic glass of the Portezuelo Ignimbrite and a lava flow of the Vitreous Trachytes lithofacies has been analyzed. An estimation of the relative proportions of silicic and basaltic magmas present in hybrid lavas has been carried out using least squares approximation as described by Bryan et al. (1969).

\section{Results}

\subsection{Summary of the petrography and whole-rock chemistry}

The petrographic characteristics of Payún Matrú rocks are summarized in Table 2, and the whole-rock geochemistry and petrography are detailed in Hernando et al. (2012, 2014a). The petrographic and geochemical features necessary for the text are outlined. Fig. 3 shows the TAS classification diagram for the PMVF rocks. This volcanic field belongs to the alkaline series, with compositions between basalts and trachybasalts (in the eastern and western basaltic fields) and trachytes/rhyolites in the Payún Matrú and Payún Liso volcanoes (Hernando et al., 2014a). The volcanic rocks of the PMVF show a consistent pattern in Harker diagrams, as well as in REE and other multielements diagrams (Fig. 4; Hernando et al., 2014a). Mass balance and Rayleigh fractionation models show that the trachytes are a result of fractional crystallization of basalts without significant upper crustal contamination (Hernando et al., 2014a).

\subsubsection{Payún Matrú pre-caldera stage rocks}

The $T$ pre unit is the most variable in terms of its petrographic characteristics and shows compositions between basaltic trachyandesites and trachytes, with a clear predominion of the latter (Fig. 3 ). The $T$ pre

Table 1

Location of the selected samples for mineral composition analyzes.

\begin{tabular}{|c|c|c|c|c|}
\hline Unit & Sample & Rock type & $\mathrm{S}$ & W \\
\hline$T$ pos (Tv lithofacies) & PMA 27-A & Trachyte & $36^{\circ} 25^{\prime} 41.3^{\prime \prime}$ & $69^{\circ} 09^{\prime} 36.5^{\prime \prime}$ \\
\hline T pos ( $T$ bq lithofacies) & PM 40 & Trachyte & $36^{\circ} 23^{\prime} 38.5^{\prime \prime}$ & $69^{\circ} 13^{\prime} 13.3^{\prime \prime}$ \\
\hline TA pos & PM 34 & $\begin{array}{l}\text { Basaltic } \\
\text { trachyandesite }\end{array}$ & $36^{\circ} 23^{\prime} 25.1^{\prime \prime}$ & $69^{\circ} 13^{\prime} 01.5^{\prime \prime}$ \\
\hline TA pos & STA 6B & Trachyandesite & $36^{\circ} 20^{\prime} 00.1^{\prime \prime}$ & $69^{\circ} 18^{\prime} 42.6^{\prime \prime}$ \\
\hline TA pos & STA 38 & $\begin{array}{l}\text { Basaltic } \\
\text { trachyandesite }\end{array}$ & $36^{\circ} 28^{\prime} 00.1^{\prime \prime}$ & $69^{\circ} 17^{\prime} 44.7^{\prime \prime}$ \\
\hline $\operatorname{Ig} P$ & PM 14 & Trachyte & $36^{\circ} 22^{\prime} 30.0^{\prime \prime}$ & $69^{\circ} 11^{\prime} 49.4^{\prime \prime}$ \\
\hline $\operatorname{Ig} P$ & PMB 44 & - & $36^{\circ} 23^{\prime} 13.6^{\prime \prime}$ & $69^{\circ} 18^{\prime} 35.3^{\prime \prime}$ \\
\hline Tpre & PM 27 & Trachyte & $36^{\circ} 22^{\prime} 50.9^{\prime \prime}$ & $69^{\circ} 10^{\prime} 59.5^{\prime \prime}$ \\
\hline Tpre & PM 28 & Trachyte & $36^{\circ} 22^{\prime} 01.9^{\prime \prime}$ & $69^{\circ} 10^{\prime} 48.9^{\prime \prime}$ \\
\hline Tpre & PY 10 & Trachyte & $36^{\circ} 24^{\prime} 37.5^{\prime \prime}$ & $69^{\circ} 06^{\prime} 36.0^{\prime \prime}$ \\
\hline B posII & PM 46 & Trachybasalt & $36^{\circ} 20^{\prime} 16.2^{\prime \prime}$ & $69^{\circ} 23^{\prime} 44.0^{\prime \prime}$ \\
\hline B posII & PY 13 & Trachybasat & $36^{\circ} 23^{\prime} 44.9^{\prime \prime}$ & $69^{\circ} 03^{\prime} 29.6^{\prime \prime}$ \\
\hline B pre & PY 5 & Trachybasalt & $36^{\circ} 18^{\prime} 09.2^{\prime \prime}$ & $69^{\circ} 04^{\prime} 41.5^{\prime \prime}$ \\
\hline
\end{tabular}


Table 2

Summary of the petrography of PMVF rocks.

\begin{tabular}{|c|c|c|c|c|c|c|c|c|c|c|c|}
\hline \multirow[t]{2}{*}{ Unit } & \multicolumn{9}{|c|}{ Phenocrysts } & \multirow{2}{*}{$\begin{array}{l}\mathrm{SiO}_{2} \\
\text { (wt.\%) }\end{array}$} & \multirow{2}{*}{$\begin{array}{l}\text { Mingling/mixing } \\
\text { textures }\end{array}$} \\
\hline & Ol & Opx & Cpx & Amp & $\mathrm{Bt}$ & $\mathrm{Pl}$ & Af & Opq & Apt & & \\
\hline T pre (I) & \pm & - & 0 & \pm & \pm & - & 0 & 0 & 0 & $66.6-67.7$ & $\mathrm{r}$ \\
\hline Tpre (II) & \pm & - & 0 & $r$ & $r$ & 0 & 0 & 0 & 0 & $60.3-64.3$ & \pm \\
\hline T pre (III) & 0 & $r$ & \pm & \pm & \pm & 0 & - & 0 & \pm & $52.4-63.7$ & \pm \\
\hline T pre (IV) & 0 & - & \pm & - & - & 0 & - & 0 & $r$ & 56.5 & \pm \\
\hline $\operatorname{Ig} P$ & 0 & - & 0 & $r$ & 0 & o & 0 & 0 & 0 & $62.0-65.1$ & - \\
\hline TA pos & 0 & - & 0 & $r$ & - & 0 & - & 0 & $\mathrm{r}$ & $52.7-60.0$ & \pm \\
\hline T bq (T pos) & \pm & - & 0 & $\mathrm{r}$ & \pm & \pm & 0 & 0 & 0 & $66.4-68.2$ & - \\
\hline C pz (T pos) & 0 & - & 0 & - & \pm & $r$ & 0 & 0 & 0 & $?$ & - \\
\hline$T v(T$ pos $)$ & 0 & - & 0 & - & \pm & $r$ & 0 & 0 & 0 & $67.6-68.7$ & - \\
\hline B pre/pos & o & - & \pm & - & - & \pm & - & 0 & $r$ & $46.5-49.7$ & \pm \\
\hline
\end{tabular}

0 : always present.

\pm : present in some samples.

-: absent.

r: rare (present in few samples).

unit rocks were divided in four types according to the phenocrysts found: (1) Type I: phenocrysts of alkali feldspars (5-18\%), clinopyroxene $(<3 \%)$, olivine in some cases $(<1 \%)$, and rarely amphibole or biotite $(<2 \%)$, plus apatite and opaque minerals. The groundmass is pilotaxitic; (2) Type II: phenocrysts of alkali feldspars (3-12\%), plagioclase (2-14\%), clinopyroxene $(<3 \%)$, olivine in some cases $(<3 \%)$, and rarely amphibole or biotite $(<3 \%)$, plus apatite and opaque minerals. The groundmass is pilotaxitic. (3) Type III: phenocrysts of plagioclase (3-18\%) and olivine $(<3 \%) \pm$ clinopyroxene $(<5 \%) \pm$ biotite $(<4 \%) \pm$ amphibole (rare), plus apatite and opaque minerals. The groundmass is pilotaxitic. This type is the most abundant of the T pre unit; and (4)) Type IV: phenocrysts of plagioclase $(1-20 \%)$, olivine $(<5 \%) \pm$ clinopyroxene $(<$ $4 \%) \pm$ apatite, plus opaque minerals. The groundmass is intergranular.

Some lavas of this unit have two texturally different groundmasses, characterized by a fluid-fluid relationship, and scarce lavas present ellipsoidal mafic enclaves up to a few centimeters in diameter, with crenulated margins (Fig. 5a). The mineralogical disequilibrium textures in this unit are abundant and detailed in Hernando et al. (2012). These textures include coarse sieved feldspars, feldspars with markedly rounded corners, dusty-sieved plagioclases along with coarse sieved, and clean plagioclases (rounded and euhedral crystals in both types of sieved crystals), anti-rapakivi texture (rare), biotite replaced by anhydrous minerals (Fig. 5b), rounded and non-rounded olivine and clinopyroxenes phenocrysts together in the same thin section, and rounded amphibole phenocrysts with an opaque rim.

\subsubsection{Payún Matrú syn-caldera stage rocks}

The syn-caldera unit (Portezuelo Ignimbrite) has a trachytic composition (Fig. 3) and includes crystals of alkali feldspars ( $<5 \%$ ), plagioclases $(4-16 \%)$, olivine $(<3 \%)$, clinopyroxene $(<3 \%)$, biotite $(<3 \%)$, and opaques, plus apatite as accessory phase. Amphibole is present but extremely rare (a few thin sections with only a single crystal). The crystal content of pumice/fiamme on a vesicle-free basis is variable but less than 30\%. Feldspars are clean and a minor proportion shows sieved interiors or rims (Fig. 5c). Olivine and clinopyroxenes are euhedral to subhedral, with some crystals with rounded corners. Biotite is mostly unreacted, with some crystal replaced by opaques and a clearly minor proportion of biotite replaced by a mosaic of anhydrous minerals. Lithic clasts are volcanic, and petrographically similar to $T$ pre rocks. Lithics content is generally less than $15 \%$ (percentages based on field observations), although it can be locally higher. The Portezuelo Ignimbrite also includes spatter clasts of trachytic composition similar to the fiamme composition (Hernando et al., 2014a).

\subsubsection{Payún Matrú post-caldera stage rocks}

The Post-caldera Trachyandesites are lava flows of intermediate composition (Fig. 3), porphyritic with plagioclase (10-22\%), olivine (2-5\%), clinopyroxene (2-5\%), opaques, apatite, and amphibole in only one lava $(<1 \%)$. Phenocrysts of plagioclase have a variety of textures; most are euhedral to sub-anhedral rounded clean crystals, and some are fine to coarse sieved (rounded or euhedral; Fig. 5d), and

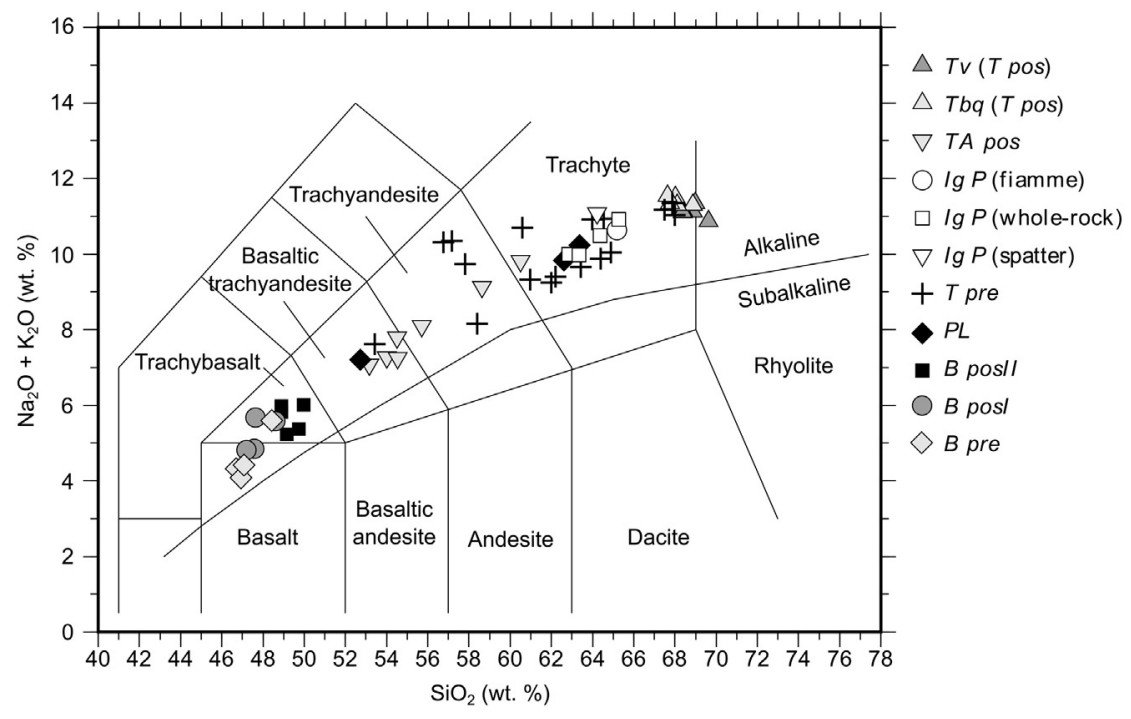

Fig. 3. TAS classification diagram of PMVF rocks, modified from Hernando et al. (2014a). 


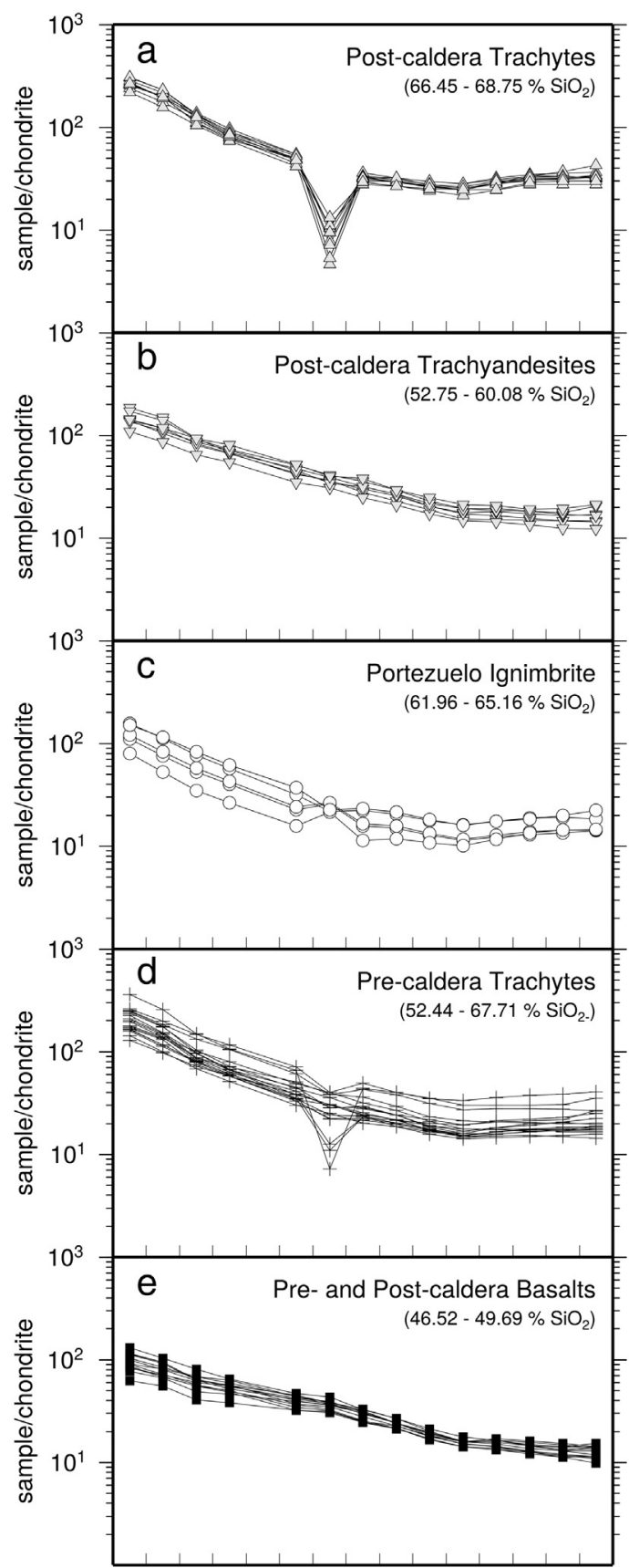

La Ce Pr NdPmSm Eu Gd Tb Dy Ho Er Tm Yb Lu

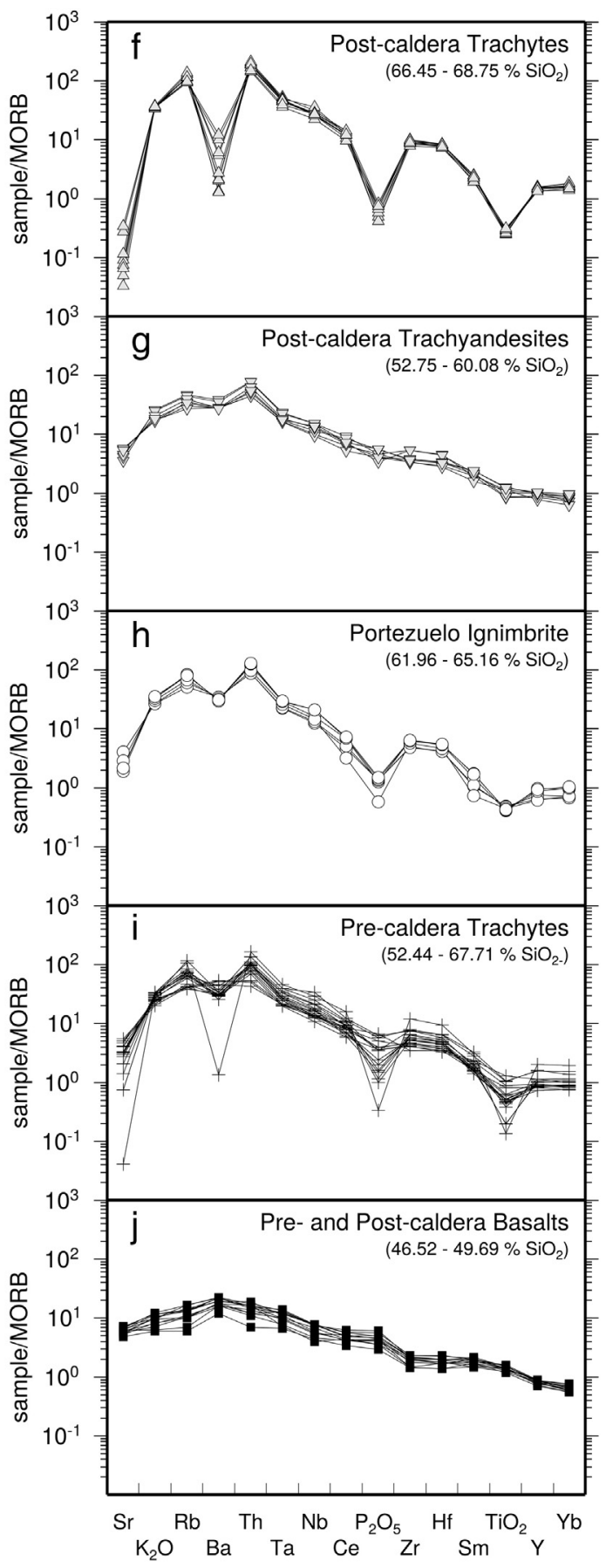

Fig. 4. a-e) REE diagrams of PMVF rocks, modified from Hernando et al. (2014a). f-j) Incompatible trace elements diagrams for PMVF rocks, modified from Hernando et al. (2014a).

both types are present in the same thin section (Fig. 5e). Olivine and clinopyroxene phenocrysts show mostly rounded corners, along with euhedral crystals; some olivines are embayed. The intra-caldera flow of this unit shows mingling texture, with most of the flow with basaltic trachyandesitic composition, and a restrained sector with trachytic composition (Fig. 3; Hernando et al., 2012). The T pos unit is represented by porphyritic lavas and pumice clasts with alkali feldspar (5-20\%), olivine $(<3 \%)$, clinopyroxene $(<4 \%)$, and biotite in some cases $(<2 \%)$, plus opaque minerals and apatite (Fig. 5f). The $T b q$ and $T v$ lithofacies of this unit have a homogeneous trachytic composition (Hernando et al., 2014a; Fig. 3). This unit does not show evidence of disequilibrium textures which could suggest magma mixing or mingling.

\subsubsection{Basaltic fields rocks}

The basaltic lavas of the pre- and post-caldera stages of the PMVF are porphyritic with olivine $(1-5 \%) \pm$ clinopyroxene $(<5 \%) \pm$ plagioclase (generally $<5 \%$, rarely up to $10 \%$ ) + opaques, with an intergranular groundmass. There are also several basaltic flows that have two different intergranular groundmasses with a fluid relationship between them.

\subsection{Mineral chemistry}

\subsubsection{Feldspars}

The composition of feldspars of the Pre-caldera Trachytes unit is highly variable (Table 3 ). Twelve feldspars of this unit were analyzed 


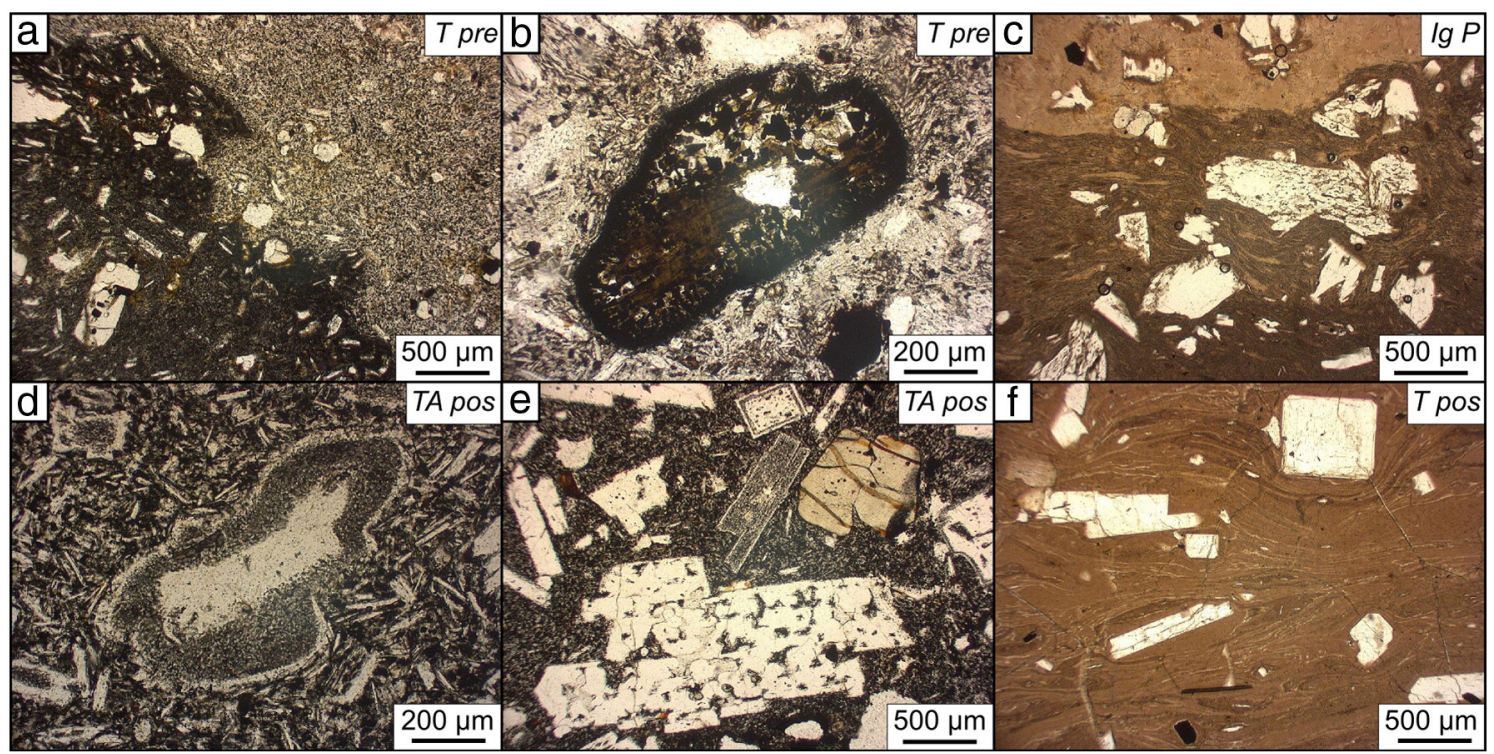

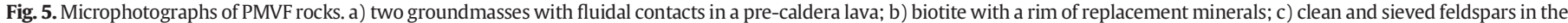

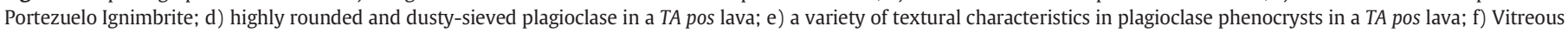
Trachytes lava, with clean and euhedral alkali feldspars set in brownish volcanic glass.

(four to seven analyses in each phenocryst and two in each groundmass feldspar). A dyke exposed in the caldera wall (sample PM 27; Fig. 2a) presents plagioclase phenocrysts of $\mathrm{An}_{20-72}$ and a groundmass with plagioclase of $\mathrm{An}_{28-29}$. A coarse sieved phenocryst has a homogeneous composition from core to rim of $A_{26-39}$, a clean plagioclase has a similar composition but with a wider range $\left(\mathrm{An}_{20-37}\right)$, and a rim-sieved plagioclase located in a glomerule presents a labradoritic composition $\left(A n_{57-72}\right)$ with an oligoclase rim $\left(\mathrm{An}_{26-30}\right)$. A lava flow also exposed by the caldera collapse (sample PM 28; Fig. 2a) presents a clean plagioclase phenocryst with rounded corners and a composition of $A_{51-59}$

Table 3

Selected feldspars analyses of the PMVF rocks.

\begin{tabular}{|c|c|c|c|c|c|c|c|c|c|c|c|}
\hline Unit & $T v$ & $T b q$ & TA pos & TA pos & TA pos & TA pos & TA pos & TA pos & TA pos & $\operatorname{Ig} P$ & $\operatorname{Ig} P$ \\
\hline Sample & PMA 27 A & PM 40 & PM 34 & PM 34 & PM 34 & STA 6B & STA 38 & STA 38 & STA 38 & PM 14 & PMB 44 \\
\hline \multicolumn{12}{|l|}{$\%$} \\
\hline $\mathrm{SiO}_{2}$ & 66.39 & 65.77 & 52.16 & 46.70 & 58.89 & 54.97 & 51.15 & 57.38 & 55.86 & 63.94 & 58.29 \\
\hline $\mathrm{Al}_{2} \mathrm{O}_{3}$ & 19.85 & 19.69 & 30.18 & 34.36 & 25.30 & 28.28 & 30.52 & 26.29 & 26.41 & 21.20 & 25.37 \\
\hline $\mathrm{TiO}_{2}$ & 0.00 & 0.19 & 0.19 & 0.12 & 0.26 & 0.05 & 0.21 & 0.12 & 0.35 & 0.09 & 0.04 \\
\hline $\mathrm{Fe}_{2} \mathrm{O}_{3}$ & 0.16 & 0.19 & 0.54 & 0.58 & 0.40 & 0.53 & 0.47 & 0.56 & 1.00 & 0.19 & 0.43 \\
\hline $\mathrm{MnO}$ & 0.00 & 0.00 & 0.03 & 0.01 & 0.02 & 0.03 & 0.00 & 0.02 & 0.01 & 0.00 & 0.00 \\
\hline $\mathrm{MgO}$ & 0.01 & 0.00 & 0.03 & 0.05 & 0.06 & 0.06 & 0.06 & 0.06 & 0.06 & 0.00 & 0.02 \\
\hline $\mathrm{CaO}$ & 0.63 & 0.56 & 12.43 & 16.96 & 6.59 & 10.12 & 12.78 & 8.12 & 8.15 & 2.28 & 7.36 \\
\hline $\mathrm{Na}_{2} \mathrm{O}$ & 6.69 & 7.19 & 4.22 & 1.85 & 6.42 & 5.52 & 3.93 & 5.86 & 6.01 & 7.12 & 6.86 \\
\hline $\mathrm{K}_{2} \mathrm{O}$ & 6.80 & 6.23 & 0.39 & 0.10 & 1.61 & 0.51 & 0.33 & 1.19 & 0.90 & 4.55 & 0.81 \\
\hline $\mathrm{SrO}$ & 0.10 & 0.00 & 0.21 & 0.27 & 0.26 & 0.32 & 0.20 & 0.20 & 0.14 & 0.17 & 0.00 \\
\hline $\mathrm{BaO}$ & 0.00 & 0.12 & 0.02 & 0.00 & 0.08 & 0.02 & 0.00 & 0.00 & 0.13 & 0.31 & 0.04 \\
\hline Total & 100.63 & 99.93 & 100.37 & 101.00 & 99.89 & 100.41 & 99.64 & 99.79 & 99.01 & 99.83 & 99.32 \\
\hline An & 3 & 3 & 61 & 83 & 33 & 49 & 63 & 41 & 41 & 11 & 35 \\
\hline $\mathrm{Ab}$ & 58 & 62 & 37 & 16 & 57 & 48 & 35 & 52 & 54 & 62 & 60 \\
\hline Or & 39 & 35 & 2 & 1 & 10 & 3 & 2 & 7 & 5 & 27 & 5 \\
\hline Unit & Tpre & T pre & Tpre & T pre & T pre & T pre & T pre & B pre & B posII & B posII & B posII \\
\hline$\overline{\text { Sample }}$ & $\overline{\mathrm{PM}} 27$ & $\overline{\text { PM } 28}$ & $\overline{\mathrm{PM} 28}$ & PY 10 & $\overline{\text { PY } 10}$ & PY 10 & $\overline{\text { PY } 10}$ & PY 5 & $\overline{\text { PY } 13}$ & $\overline{\mathrm{PM} 46}$ & $\overline{\mathrm{PM} 46}$ \\
\hline \multicolumn{12}{|l|}{$\%$} \\
\hline $\mathrm{SiO}_{2}$ & 61.13 & 55.57 & 57.82 & 52.04 & 62.39 & 55.70 & 59.69 & 50.44 & 49.49 & 46.19 & 50.79 \\
\hline $\mathrm{Al}_{2} \mathrm{O}_{3}$ & 23.89 & 28.68 & 26.03 & 30.79 & 22.24 & 27.59 & 24.61 & 30.99 & 30.97 & 33.50 & 30.31 \\
\hline $\mathrm{TiO}_{2}$ & 0.07 & 0.00 & 0.00 & 0.00 & 0.24 & 0.14 & 0.19 & 0.24 & 0.05 & 0.05 & 0.09 \\
\hline $\mathrm{Fe}_{2} \mathrm{O}_{3}$ & 0.28 & 0.58 & 0.46 & 0.12 & 0.38 & 0.45 & 0.54 & 0.75 & 0.74 & 0.60 & 1.00 \\
\hline $\mathrm{MnO}$ & 0.01 & 0.01 & 0.01 & 0.01 & 0.01 & 0.00 & 0.00 & 0.00 & 0.02 & 0.00 & 0.00 \\
\hline $\mathrm{MgO}$ & 0.00 & 0.07 & 0.00 & 0.02 & 0.00 & 0.04 & 0.00 & 0.10 & 0.09 & 0.06 & 0.11 \\
\hline $\mathrm{CaO}$ & 5.29 & 10.49 & 7.56 & 12.53 & 3.35 & 9.58 & 5.91 & 13.41 & 14.25 & 17.11 & 13.75 \\
\hline $\mathrm{Na}_{2} \mathrm{O}$ & 7.49 & 5.33 & 6.68 & 4.10 & 7.59 & 5.80 & 7.30 & 3.50 & 3.31 & 1.79 & 3.78 \\
\hline $\mathrm{K}_{2} \mathrm{O}$ & 1.47 & 0.45 & 0.74 & 0.26 & 2.85 & 0.50 & 0.99 & 0.21 & 0.22 & 0.08 & 0.24 \\
\hline $\mathrm{SrO}$ & 0.19 & 0.27 & 0.22 & 0.25 & 0.15 & 0.36 & 0.26 & 0.28 & 0.26 & 0.13 & 0.25 \\
\hline $\mathrm{BaO}$ & 0.11 & 0.03 & 0.11 & 0.00 & 0.15 & 0.03 & 0.22 & 0.02 & 0.00 & 0.01 & 0.00 \\
\hline Total & 99.93 & 101.47 & 99.62 & 100.10 & 99.35 & 100.19 & 99.71 & 99.95 & 99.39 & 99.51 & 100.33 \\
\hline An & 26 & 51 & 37 & 62 & 17 & 47 & 30 & 67 & 70 & 84 & 66 \\
\hline $\mathrm{Ab}$ & 65 & 46 & 58 & 36 & 66 & 50 & 64 & 32 & 29 & 16 & 33 \\
\hline Or & 9 & 3 & 5 & 2 & 17 & 3 & 6 & 1 & 1 & 0 & 1 \\
\hline
\end{tabular}




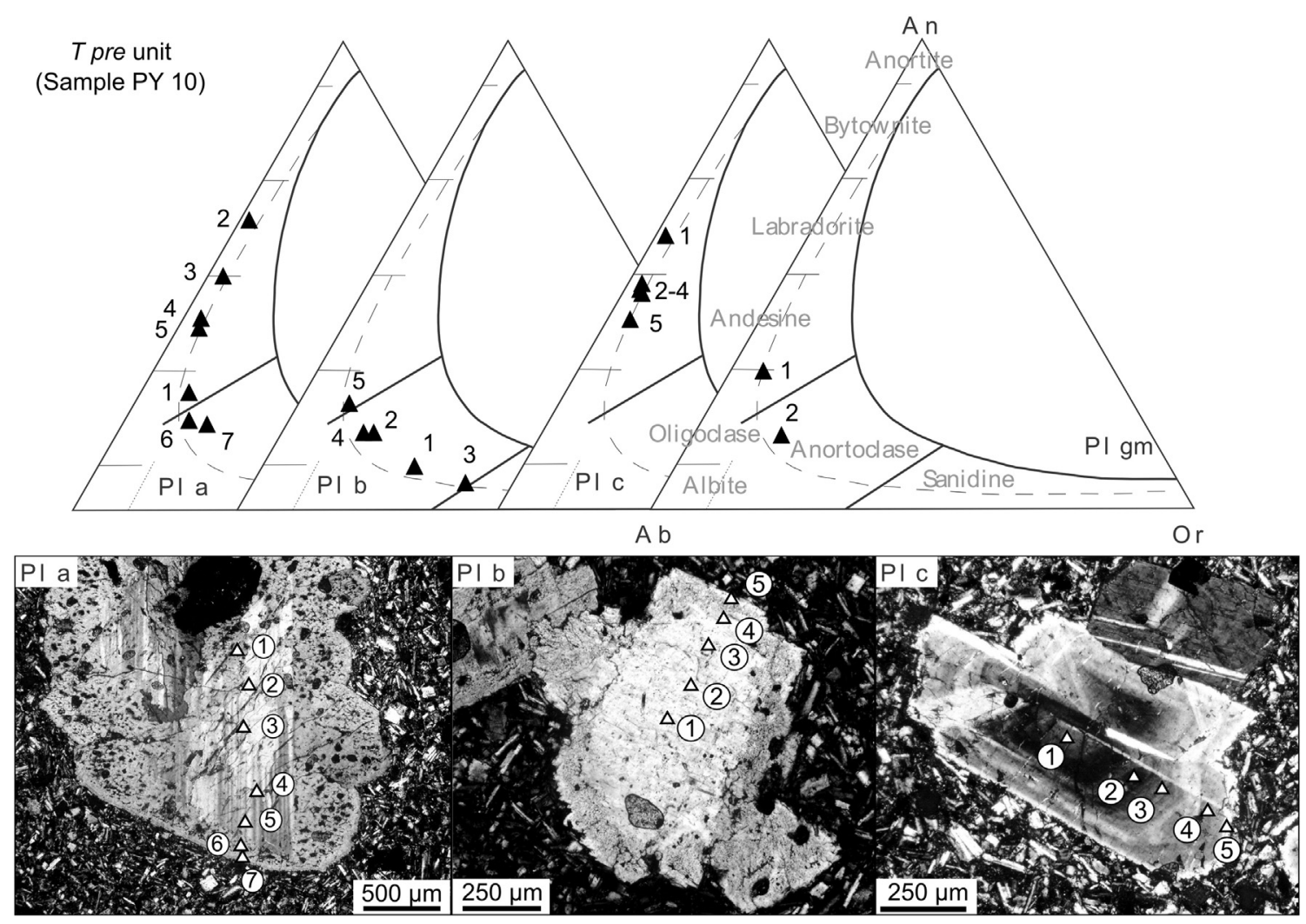

Fig. 6. Feldspar compositions of sample PY 10 of the T pre unit. Pl: plagioclase; gm: groundmass.

and an An-poor rim of $\mathrm{An}_{38}$, an anhedral and coarse sieved plagioclase of andesine composition $\left(\mathrm{An}_{36-41}\right)$ and, an anhedral plagioclase with an outer sieved rim of relatively homogeneous composition $\left(\mathrm{An}_{32-43}\right)$. Finally, a lava flow exposed outside the caldera rim (sample PY 10; Fig. 2a) presents the widest amplitude of feldspar composition of this unit $\left(\mathrm{An}_{6-62}-\mathrm{Ab}_{36-69}-\mathrm{Or}_{2-39}\right)$. A rounded phenocryst presents an inner zone of $\mathrm{An}_{39-62}$ and an outer sieved rim of oligoclase/anorthoclase composition (Fig. 6). An anhedral phenocryst with a sieved rim varies from oligoclase to almost sanidine $\left(\mathrm{An}_{6-23}-\mathrm{Ab}_{55-68}-\mathrm{Or}_{9-39}\right.$; Fig. 5). A third phenocryst analyzed is an euhedral and clean labradorite-andesine plagioclase ( $\mathrm{An}_{40-58}$; Fig. 6).

Three alkali feldspars of the syn-caldera unit (Portezuelo Ignimbrite) located in fiamme and matrix have a homogeneous anorthoclase composition of $\mathrm{An}_{10-12}-\mathrm{Ab}_{61-63}-\mathrm{Or}_{25-29}$ (three to five analyses in each crystal; Fig. 7). The feldspars located in the moderately vesicular spatter clasts within the Portezuelo Ignimbrite have a different composition (two analyses performed in each crystal). Four feldspars are andesine plagioclases, with compositions of $\mathrm{An}_{32-36}$, while one crystal of feldspar is anorthoclase similar to the others $\left(\mathrm{An}_{11-12}-\mathrm{Ab}_{65-66}-\mathrm{Or}_{22-23}\right)$.

The lava flows of the Post-caldera Trachyandesites unit present a wide variety of textures in plagioclases (Hernando et al., 2012, 2014a). Fourteen plagioclases were selected for analysis (three to six analyses in each phenocryst, and one or two analyses in groundmass plagioclase). The three lavas with available plagioclase compositions also present great amplitude of compositions (Fig. 7): between $\mathrm{An}_{33}$ and $\mathrm{An}_{83}$ for the intra-caldera flow (sample PM 34; Figs. 2a and 8), between $A n_{21}$ and $A n_{67}$ (with the rim of one crystal with $A n_{5}$ ) for sample STA 6B (Fig. 2a), and between $A_{24}$ and $A n_{67}$ for sample STA 38 (Fig. 2a). As an example, sample PM 34 of the intra-caldera lava flow presents (1) a dusty-sieved plagioclase with an inverse zoning in its core, a decrease

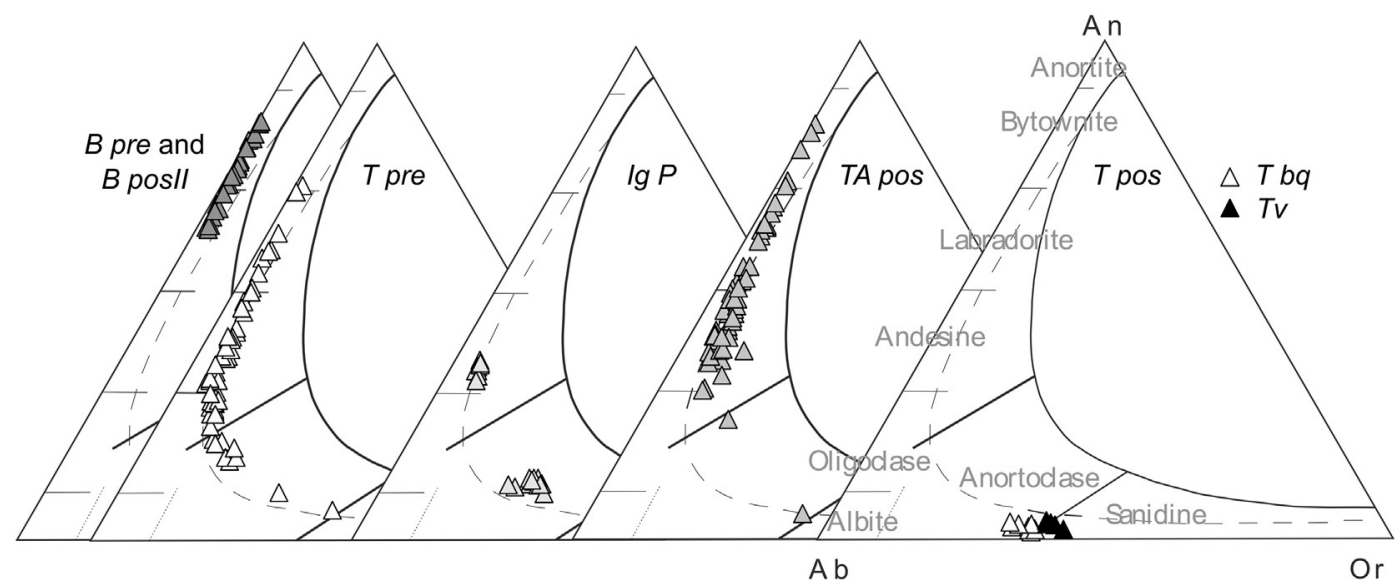

Fig. 7. Feldspar compositions for all the analyzed samples of the PMVF. 

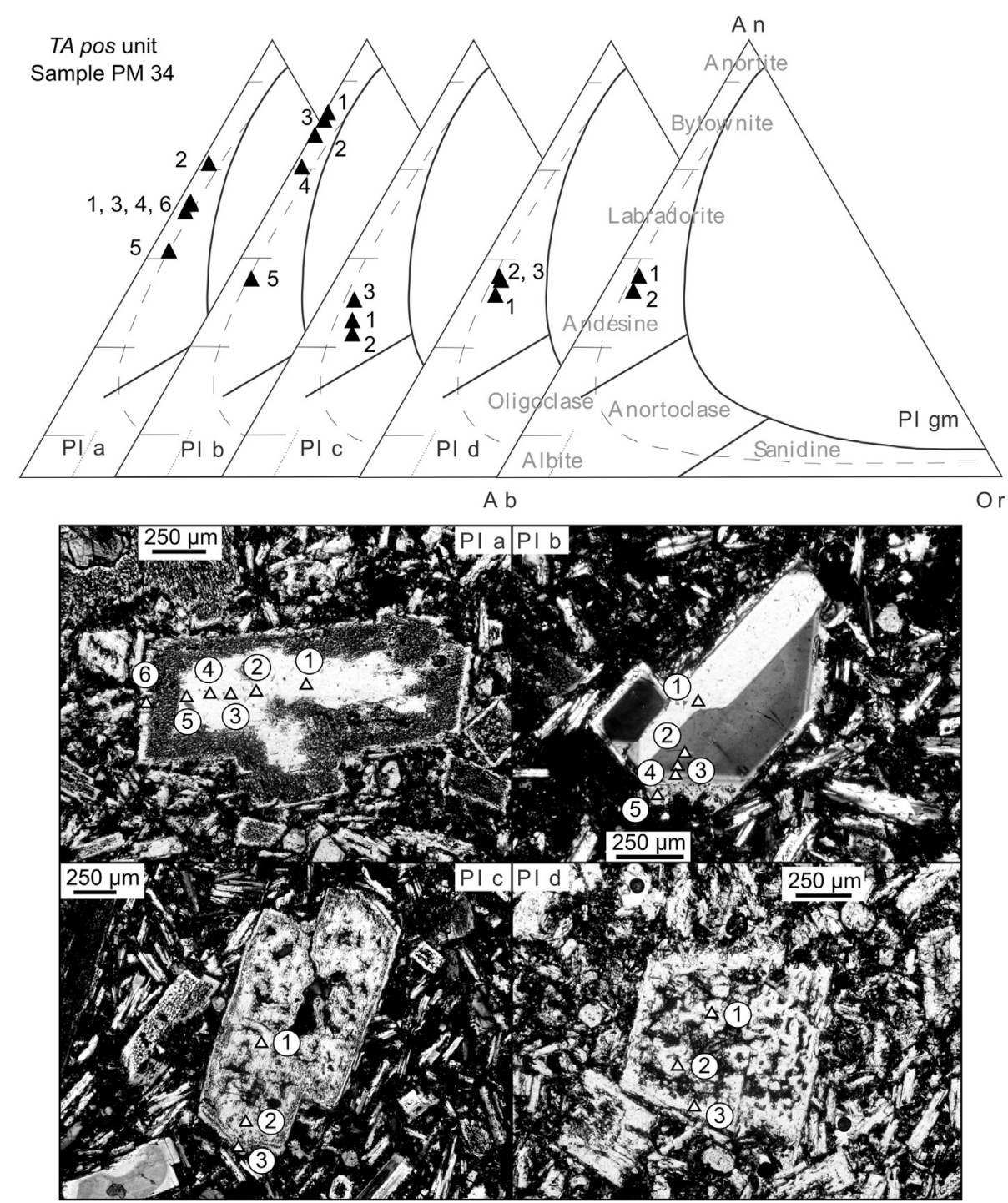

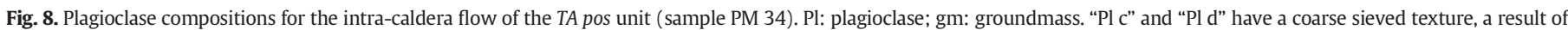
plagioclase dissolution due to decompression (Nelson and Montana, 1992). These large inclusions are filled with crystalline groundmass.

in An content in its middle part, a dusty-sieved ring and an outer rim richer in An (Pl a, Fig. 8); (2) a clean bytownitic plagioclase with a rim clearly more An-poor of andesine composition (Pl b, Fig. 8); (3) a coarse and dusty-sieved plagioclase of andesine composition $\left(\mathrm{An}_{33-40}\right)(\mathrm{Pl} \mathrm{c}$, Fig. 8); (4) a coarse sieved plagioclase of homogeneous andesine composition $\left(\mathrm{An}_{42-46}\right)$ (Pl d, Fig. 8); and (5) a groundmass constituted by plagioclase microlites with a composition of $\mathrm{An}_{43-46}$.

The alkali feldspars of the Post-caldera Trachytes unit (both Blocky Trachytes and Vitreous Trachytes lithofacies) are relatively homogeneous in their composition (five phenocrysts were analyzed, with three analyses in each crystal). Euhedral and rounded feldspars phenocrysts of the Blocky Trachytes lithofacies are anorthoclase, plotting close to the sanidine field (Fig. 7), with compositions $\mathrm{Or}_{32-37}-\mathrm{Ab}_{61-65}$. Feldspars of the Vitreous Trachytes lithofacies (with embayments and without rounded corners) are sanidine/anorthoclase (Fig. 7), with slightly higher potassium content and compositions of $\mathrm{Or}_{37-41}-\mathrm{Ab}_{56-59}$.

Phenocrysts and groundmass plagioclases of the basaltic fields units are bytownite and labradorite, with anortite contents between $59 \%$ and 84\% (thirteen plagioclases analyzed, with three to six analyses in each phenocryst and two analyses in each groundmass plagioclase; Fig. 7). Plagioclase phenocrysts in the basaltic lavas present a variety of textures, with euhedral to anhedral phenocrysts, and with sieved textures as well as clean (non-sieved) crystals present in the same sample. In each of the three analyzed samples, there is no compositional difference between the sieved and non-sieved phenocrysts. As an example, a clean and euhedral plagioclase in sample PY 13 (B posIl unit; Figs. 2a and 9) presents a composition of $A_{69-82}$ (the rim is richer in An than the middle-core of the crystal), while a sieved phenocryst presents a composition of $\mathrm{An}_{64-81}$ (the core-to-middle sieved zone is richer in An than the outer rim). Microlites in the groundmass are labradorite $\left(\mathrm{An}_{63-70}\right)$.

\subsubsection{Olivine}

Selected olivine microanalyses are reported in Table 4 and shown in Fig. 10. Olivine phenocrysts in two Pre-caldera Trachytes lavas have rounded corners and have a relatively homogeneous composition of $\mathrm{Fo}_{50-56}$. A euhedral olivine crystal hosted in fiamme of the Portezuelo Ignimbrite has a composition of $\mathrm{FO}_{53-54}$. Regarding the Post-caldera Trachyandesites unit, the composition of olivine phenocrysts varies in the three analyzed samples, with a range of $\mathrm{Fo}_{66-78}$. The most magnesian olivines correspond to sample STA 38, while the less magnesian olivine belongs to the intra-caldera lava flow (sample PM 34). In the case 


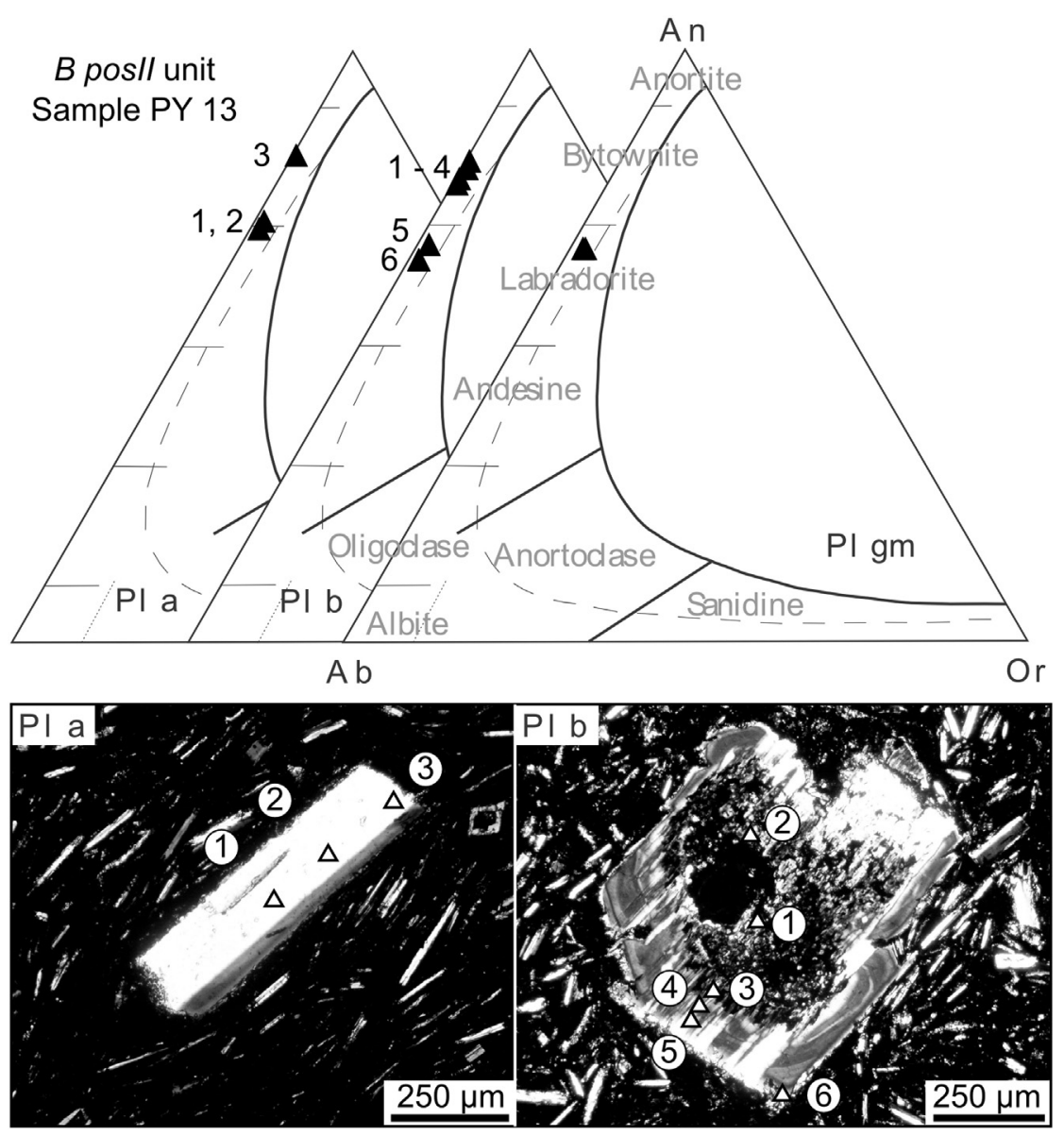

Fig. 9. Plagioclase composition for sample PY 13 of the B posII unit. Pl: plagioclase; gm: groundmass.

of the intra-caldera flow, two olivine crystals with different morphology (one euhedral and another with embayments) were analyzed, and no difference in their composition was found, with both crystals having a composition of $\mathrm{Fo}_{66-67}$. The phenocrysts of the other two flows analyzed of this unit show a weak reverse zoning (rim compositions with a Fo content $2 \%$ higher than the core). In the Post-caldera Trachytes unit, olivine was found only in the sample of the Vitreous Trachytes lithofacies, euhedral and fresh, with a composition of $\mathrm{Fo}_{44}$.

In the basaltic field lavas, the olivine composition was analyzed in three flows of the Pre-caldera Basalts and Post-caldera Basalts II units. Olivine phenocrysts are usually euhedral, with a slight skeletal morphology in one case, and with embayments in another case. The composition of all analyzed olivines, with the exception of the embayed crystal, are homogeneous, with a content of $\mathrm{Fo}_{76-79}$. The embayed olivine is richer in magnesium, with a composition of $\mathrm{Fo}_{83-85}$.

\subsubsection{Pyroxenes}

Pyroxenes present in PMVF rocks are clinopyroxenes, with the exception of rare lavas of the pre-caldera stage which present orthopyroxene. Selected pyroxene compositions are listed in Table 4. The clinopyroxene phenocrysts of the Pre-caldera Trachytes unit are augites with a compositional range of $\mathrm{Wo}_{39-44}-\mathrm{En}_{34-43}-\mathrm{Fs}_{15-23}$ (Fig. 11a). Clinopyroxenes are euhedral, with the exception of the lava flow east of the caldera (sample PY 10), which presents also clinopyroxenes with rounded corners within glomerules. Those crystals usually present an inverse zoning, with a lesser ferrosilite content and a higher \#Mg toward the crystal margin. The analyzed clinopyroxene of sample PM 27 presents a \#Mg 5\% higher in the margin than in its core, whereas this difference is around $10 \%$ in one of the analyzed crystals of sample PY 10 (Fig. 11a). Sample PY 10 presents also orthopyroxene in small glomerules, with compositions within the enstatite field $\left(\mathrm{Wo}_{3}-\mathrm{En}_{48-52}-\mathrm{Fs}_{45-48}\right)$ (Fig. 11a).

Clinopyroxene crystals in the matrix and trachytic spatter clasts of the Portezuelo Ignimbrite are euhedral-subhedral. They are relatively homogeneous in composition, although they present greater diopside content in the spatter clasts (Fig. 11b). The clinopyroxene in the matrix present a normal zoning and a composition of $\mathrm{Wo}_{43}-\mathrm{En}_{37-39}-\mathrm{Fs}_{18-20}$, while the one in the spatter clast has also a normal zoning and a composition of $\mathrm{Wo}_{44-46}-\mathrm{En}_{38-41}-\mathrm{Fs}_{15-16}$. Clinopyroxene phenocrysts of the Post-caldera Trachyandesites unit are all calcic augites with compositions of $\mathrm{Wo}_{42-44}-\mathrm{En}_{40-45}-\mathrm{Fs}_{13-16}$ (Fig. 11c). The concentric and sector zoning present in some phenocrysts are reflected in the $\mathrm{TiO}_{2}$ content and \#Mg (Table 4). These zoned phenocrysts usually present an increase of the \#Mg toward the margin of the crystal, indicating an inverse zoning. The greatest variation of the \#Mg in a single phenocrysts is found in sample STA 6B. In this sample, the core of the clinopyroxene phenocryst presents a \#Mg similar to the rest of the clinopyroxenes of this unit (\#Mg = 60-62), while the middle and outer margin present a \#Mg of 64-67 (similar to the phenocrysts present in the basaltic lavas). The clinopyroxene phenocrysts analyzed in the Blocky Trachytes and Vitreous Trachytes lithofacies (Post-caldera Trachytes unit) are augites similar in composition, with contents of $\mathrm{Wo}_{39-41}-\mathrm{En}_{37-38}-\mathrm{Fs}_{22-24}$ (Fig. 11b). The \#Mg in these phenocrysts indicates a slight normal zoning (\#Mg in the range of 49-52).

The analyzed clinopyroxene phenocrysts of the basaltic field lavas are more calcic than those of Payún Matrú (Fig. 11d). They correspond to diopside with compositions of $\mathrm{Wo}_{45-48}-\mathrm{En}_{39-43}-\mathrm{Fs}_{11-14}$. The analyzed clinopyroxenes are subhedral to euhedral, with rounded corners in the case of sample PY 5 ( $B$ pre unit), and concentric zoning in some cases which is reflected in the \#Mg (between 62 and 69). 
Table 4

Selected analyses of olivine and clinopyroxene phenocrysts of PMVF rocks.

\begin{tabular}{|c|c|c|c|c|c|c|c|c|c|c|c|}
\hline \multicolumn{12}{|l|}{ Olivine } \\
\hline Unit & $T v$ & TA pos & TA pos & TA pos & $\operatorname{Ig} P$ & T pre & T pre & B posII & B posII & B posII & B pre \\
\hline Sample & PMA 27 A & PM 34 & STA 6B & STA 38 & PM 14 & PM 27 & PM 28 & PY 13 & PM 46 & PM 46 & PY 5 \\
\hline \multicolumn{12}{|l|}{$\%$} \\
\hline $\mathrm{SiO}_{2}$ & 33.77 & 36.54 & 36.75 & 38.15 & 34.46 & 34.47 & 34.32 & 37.78 & 37.38 & 39.47 & 37.57 \\
\hline $\mathrm{TiO}_{2}$ & 0.00 & 0.07 & 0.04 & 0.09 & 0.00 & 0.00 & 0.00 & 0.00 & 0.13 & 0.02 & 0.02 \\
\hline $\mathrm{Al}_{2} \mathrm{O}_{3}$ & 0.00 & 0.04 & 0.05 & 0.03 & 0.00 & 0.02 & 0.00 & 0.06 & 0.03 & 0.05 & 0.05 \\
\hline $\mathrm{FeO}$ & 43.69 & 29.57 & 27.85 & 20.90 & 37.18 & 35.70 & 40.16 & 19.70 & 22.28 & 14.41 & 20.68 \\
\hline $\mathrm{MnO}$ & 2.81 & 0.71 & 1.05 & 0.27 & 1.62 & 1.35 & 1.67 & 0.32 & 0.34 & 0.22 & 0.30 \\
\hline $\mathrm{MgO}$ & 19.18 & 32.71 & 34.90 & 40.85 & 24.80 & 26.19 & 23.87 & 40.89 & 39.10 & 45.26 & 40.29 \\
\hline $\mathrm{CaO}$ & 0.16 & 0.25 & 0.11 & 0.17 & 0.16 & 0.14 & 0.16 & 0.26 & 0.25 & 0.29 & 0.26 \\
\hline $\mathrm{Na}_{2} \mathrm{O}$ & 0.00 & 0.00 & 0.04 & 0.00 & 0.01 & 0.03 & 0.06 & 0.04 & 0.03 & 0.00 & 0.03 \\
\hline $\mathrm{K}_{2} \mathrm{O}$ & 0.00 & 0.01 & 0.00 & 0.00 & 0.01 & 0.02 & 0.00 & 0.00 & 0.00 & 0.01 & 0.00 \\
\hline $\mathrm{Cr}_{2} \mathrm{O}_{3}$ & 0.00 & 0.00 & 0.00 & 0.00 & 0.00 & 0.00 & 0.01 & 0.00 & 0.00 & 0.01 & 0.00 \\
\hline $\mathrm{NiO}$ & 0.00 & 0.03 & 0.00 & 0.07 & 0.00 & 0.00 & 0.00 & 0.11 & 0.09 & 0.17 & 0.05 \\
\hline Total & 99.60 & 99.92 & 100.78 & 100.53 & 98.25 & 97.91 & 100.26 & 99.17 & 99.62 & 99.91 & 99.26 \\
\hline Fo & 42 & 66 & 68 & 77 & 53 & 56 & 50 & 78 & 75 & 85 & 77 \\
\hline \multicolumn{12}{|c|}{ Clinopyroxene } \\
\hline Unit & $T v$ & $T b q$ & TA pos & TA pos & $\operatorname{Ig} P$ & Tpre & Tpre & Tpre & B posII & B posII & B pre \\
\hline Sample & PMA 27 A & PM 40 & PM 34 & STA 6B & PM 14 & PM 27 & PM 28 & PY 10 & PY 13 & PM 46 & PY 5 \\
\hline \multicolumn{12}{|l|}{$\%$} \\
\hline $\mathrm{SiO}_{2}$ & 52.16 & 51.93 & 51.32 & 49.18 & 51.73 & 52.71 & 51.54 & 52.80 & 49.08 & 45.90 & 49.22 \\
\hline $\mathrm{TiO}_{2}$ & 0.18 & 0.39 & 0.40 & 1.88 & 0.19 & 0.44 & 0.40 & 0.30 & 1.76 & 1.86 & 1.13 \\
\hline $\mathrm{Al}_{2} \mathrm{O}_{3}$ & 0.57 & 0.64 & 1.17 & 4.90 & 0.91 & 0.93 & 0.99 & 0.80 & 5.15 & 8.16 & 4.54 \\
\hline $\mathrm{FeO}$ & 13.29 & 12.25 & 9.27 & 8.49 & 11.52 & 12.53 & 11.26 & 12.29 & 6.83 & 7.41 & 7.57 \\
\hline $\mathrm{MnO}$ & 1.40 & 1.17 & 0.82 & 0.28 & 0.74 & 0.93 & 0.76 & 1.05 & 0.15 & 0.11 & 0.12 \\
\hline $\mathrm{MgO}$ & 13.06 & 13.01 & 14.10 & 13.72 & 12.69 & 13.62 & 14.11 & 12.93 & 14.09 & 12.87 & 14.63 \\
\hline $\mathrm{CaO}$ & 19.15 & 19.93 & 20.86 & 20.30 & 20.62 & 19.08 & 20.09 & 19.38 & 22.18 & 22.37 & 21.86 \\
\hline $\mathrm{Na}_{2} \mathrm{O}$ & 0.45 & 0.49 & 0.56 & 0.63 & 0.40 & 0.48 & 0.42 & 0.39 & 0.47 & 0.39 & 0.47 \\
\hline $\mathrm{K}_{2} \mathrm{O}$ & 0.00 & 0.00 & 0.00 & 0.01 & 0.01 & 0.00 & 0.00 & 0.00 & 0.01 & 0.01 & 0.00 \\
\hline $\mathrm{Cr}_{2} \mathrm{O}_{3}$ & 0.00 & 0.00 & 0.00 & 0.06 & 0.04 & 0.04 & 0.03 & 0.01 & 0.00 & 0.12 & 0.03 \\
\hline Total & 100.26 & 99.81 & 98.50 & 99.46 & 98.84 & 100.76 & 99.58 & 99.96 & 99.72 & 99.20 & 99.56 \\
\hline Wo & 39 & 41 & 43 & 44 & 43 & 39 & 41 & 40 & 47 & 48 & 45 \\
\hline En & 37 & 37 & 41 & 41 & 37 & 39 & 40 & 38 & 41 & 39 & 42 \\
\hline Fs & 24 & 22 & 16 & 15 & 20 & 22 & 19 & 22 & 12 & 13 & 13 \\
\hline
\end{tabular}

\subsubsection{Amphiboles}

Selected amphibole analyses are shown in Table 5. This mineral has been analyzed in two Pre-caldera Trachytes lavas and in the only Postcaldera Trachyandesites lava flow where it occurs. In all cases, the amphibole is sub-anhedral and presents an opaque rim (Fig. 12). These amphiboles correspond to group 2 or calcic amphiboles, according to the classification of Leake et al. (1997, 2004). They are further classified as kaersutite (Fig. 12), according with their content in $\mathrm{Ca}, \mathrm{Na}$, and $\mathrm{Ti}$, with the exception of amphiboles in sample PM 28 ( $T$ pre unit) which present a slightly lower Ti content and therefore are classified as pargasite or magnesiohastingsite (since there is no knowledge of the $\mathrm{Fe}^{+3}$ content, it is not possible to determine which of these two amphiboles correspond, Leake et al., 1997).

\subsubsection{Biotite}

Biotite has been analyzed only in the Pre-caldera Trachytes unit, due to its absence in the analyzed samples of the syn- and post-caldera stage of Payún Matrú volcano (Table 5). The biotite phenocrysts present a narrow opaque rim and a slight replacement by anhydrous minerals in the case of the sample PY 10 . The \#Mg of biotites vary between 53 and 62 , while the content in Ti a.p.f.u. is high, between 0.64 and 0.80 . This could be due not only to the content of Ti in the magma (and the oxides that crystallize along with the biotite) but also to the crystallization temperature, given that at a higher temperature, the solubility of $\mathrm{Ti}$ in biotite increases (Patiño Douce, 1993).

\subsubsection{Volcanic glass}

Glass composition of fiamme of the Portezuelo Ignimbrite and a lava flow of the Vitreous Trachytes lithofacies has been analyzed (Table 5).
The composition of the glass is trachytic in the case of the Portezuelo Ignimbrite $\left(\mathrm{SiO}_{2}\right.$ between 65 and 67\%, alkalis between 9 and 10\%), while it is rhyolitic in the case of the post-caldera lava $\left(68.8 \% \mathrm{SiO}_{2}\right.$ and $9.3 \%$ of alkalis).

\subsection{Geothermobarometry}

\subsubsection{Payún Matrú rocks}

Results of temperature and pressure estimations for PMVF rocks are shown in Table 6. Since lavas from the Pre-caldera Trachytes and Postcaldera Trachyandesites unit with available mineral chemical analyses present textural and compositional evidence of magma mixing/mingling, the temperature and pressure for these two units were not determined, because the necessary conditions of a close system are not archived. The most likely scenario is that the whole-rock compositions of these lavas do not represent the equilibrium liquid from which the phenocrysts crystallized. Temperature estimations were carried out in the Portezuelo Ignimbrite and Post-caldera Trachytes, where no evidence of disequilibrium are found (Table 6).

Glass thermometers in the Tv lithofacies gave temperatures of $1001 \pm 71{ }^{\circ} \mathrm{C}$ using a correction to the Helz and Thornber (1987) method after Putirka (2008), and $955 \pm 51{ }^{\circ} \mathrm{C}$ using a P-independent equation in Putirka (2008). Glass analyzed in fiamme of the Portezuelo Ignimbrite gave temperature values of $1004 \pm 71{ }^{\circ} \mathrm{C}$ (correction to the Helz and Thornber (1987) method after Putirka (2008)) and $984 \pm$ $51{ }^{\circ} \mathrm{C}$ (Putirka, 2008).

An olivine-liquid thermometer for hydrous systems using glass compositions (Putirka et al., 2007) has been used for the Tv lithofacies and $\operatorname{Ig} P$ unit only, since there is no olivine in the $T b q$ lithofacies sample 

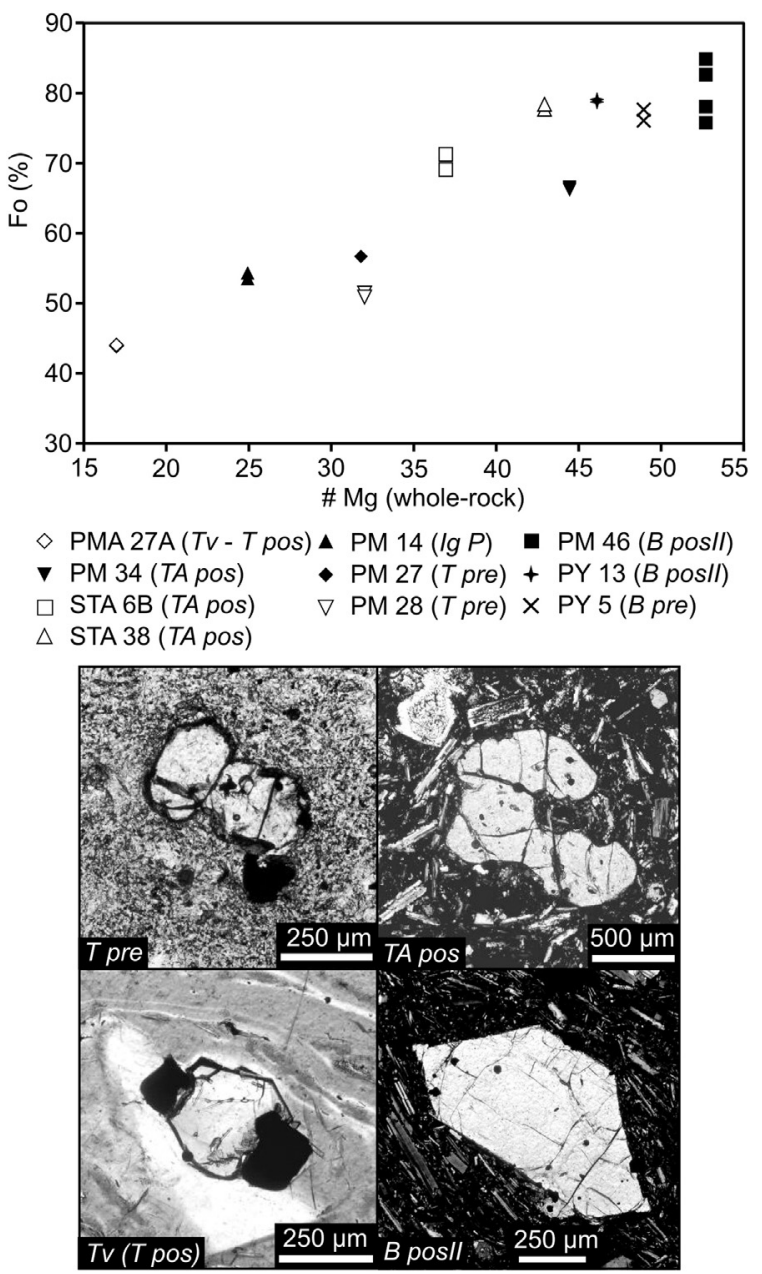

Fig. 10. Olivine compositions of PMVF rocks. A variety of olivine morphologies are shown in the microphotographs.

analyzed. In the case of the $T v$ lithofacies (sample PMA $27 \mathrm{~A}$ ), temperature estimations are between $930 \pm 29^{\circ} \mathrm{C}$ and $950 \pm 29^{\circ} \mathrm{C}$, using $a$ priori values of pressure of $0.01-0.4 \mathrm{GPa}$ (Putirka et al., 2007). Olivineglass equilibrium temperatures for the $\operatorname{Ig} P$ unit are between $933 \pm$ $29^{\circ} \mathrm{C}$ and $953 \pm 29^{\circ} \mathrm{C}$, with a priori P values of $0.01-0.4 \mathrm{GPa}$ (Putirka et al., 2007). The pressure estimations using the clinopyroxene-liquid equilibria method of Putirka et al. (2003) did not give reliable results, and therefore, the temperature estimations using the same method were not taken into account. Even when euhedral clinopyroxene without signs of disequilibrium were analyzed, the pressure estimated values were either negative or too high, for the Portezuelo Ignimbrite and the Post-caldera Trachytes.

The alkali feldspar-liquid thermometer of Putirka (2008) has been applied to the $T v$ lithofacies, the $T b q$ lithofacies, and the $I g$ $P$ unit (using the Alkali feldspar-liquid pairs in equilibrium, i.e. $\left.\mathrm{Kd}(\mathrm{An}-\mathrm{Ab})^{\mathrm{Af}-\mathrm{Liq}}=0.27 \pm 0.18\right)$. Using a priori P values in the range of 0.01-0.4 GPa, this method yields temperatures of $866 \pm 23^{\circ} \mathrm{C}$ for the $T v$ lithofacies, between $863 \pm 23{ }^{\circ} \mathrm{C}$ and $865 \pm 23{ }^{\circ} \mathrm{C}$ for the $T \mathrm{bq}$ lithofacies, and between $947 \pm 23^{\circ} \mathrm{C}$ and $951 \pm 23^{\circ} \mathrm{C}$ for the fiamme of the $\operatorname{Ig} P$ unit.

\subsubsection{Basaltic fields lavas}

In the post-caldera and pre-caldera basalts and trachybasats, the olivine-liquid thermometer can be used in two crystal-liquid pairs that have $\mathrm{Fe}-\mathrm{Mg}$ exchange coefficients $\left(\mathrm{K}_{\mathrm{D}}(\mathrm{Fe}-\mathrm{Mg})^{\mathrm{Ol}-\mathrm{Liq}}\right)$ close to the value determined in equilibrium in experiments $(0.30 \pm 0.03$; Roeder and Emslie, 1970). The other two olivine-liquid pairs analyzed do not present a $\mathrm{K}_{\mathrm{D}}(\mathrm{Fe}-\mathrm{Mg})^{\mathrm{Ol}-\mathrm{Liq}}$ value close to equilibrium, and therefore these olivines did not precipitate from the liquid used in the calculations and were not taken into account. The methods of Beattie (1993) (for anhydrous systems) and Putirka et al. (2007) (for hydrous systems) were used for temperature determinations with olivine-melt equilibria. A range of pressures between 0.4 and $1.2 \mathrm{GPa}$ has been used as a priori value for thermometric calculations (this pressure range is chosen to include and be wider than the estimated values of P; Table 6). Olivinewhole-rock thermometry for sample PM 46 (B posIl unit) gave temperatures between $1179 \pm 44^{\circ} \mathrm{C}$ and $1221 \pm 44^{\circ} \mathrm{C}$ (Beattie, 1993) and between $1174 \pm 29^{\circ} \mathrm{C}$ and $1216 \pm 29^{\circ} \mathrm{C}$ (Putirka et al., 2007). In the case of sample PY 5 ( $B$ pre unit), olivine-melt equilibria temperatures gave values between $1157 \pm 44^{\circ} \mathrm{C}$ and $1198 \pm 44^{\circ} \mathrm{C}$ (Beattie, 1993) and between $1143 \pm 29^{\circ} \mathrm{C}$ and $1185 \pm 29^{\circ} \mathrm{C}$ (Putirka et al., 2007). The method of Beattie (1993) overestimates the temperature in hydrous systems, and this could be the explanation for the slightly higher values determined by this method.

The methods of Putirka et al. (1996) and Putirka et al. (2003), based on clinopyroxene and equilibrium liquid compositions, and the method of Putirka (2008) based on clinopyroxene compositions only, have been used to estimate temperature and pressure for pre- and post-caldera basaltic units. The necessary equilibrium conditions for the calculations (i.e., $\mathrm{K}_{\mathrm{D}}(\mathrm{Fe}-\mathrm{Mg})^{\mathrm{CpxLiq}}=0.27 \pm 0.3$ ) were archived in three clinopyroxene-whole-rock pairs. The Putirka et al. (1996) method is used in mafic and anhydrous compositions, while the Putirka et al. (2003) method is used in a wider range of compositions and hydrated (subsaturated) systems. Pressures estimated for samples PM 46 and PY 13 ( $B$ posIl unit) are between $0.55 \pm 0.14 \mathrm{GPa}$ and $0.57 \pm 0.14 \mathrm{GPa}$ (Putirka et al., 1996), between $0.48 \pm 0.17 \mathrm{GPa}$ and $0.50 \pm 0.17 \mathrm{GPa}$ (Putirka et al., 2003), and between $0.57 \pm 0.15 \mathrm{GPa}$ and $0.78 \pm$ $0.15 \mathrm{GPa}$ (Putirka, 2008). In the case of sample PY 5 (B pre unit), the estimated pressures are $0.67 \pm 0.14 \mathrm{GPa}$ (Putirka et al., 1996), $0.59 \pm$ 0.17 GPa (Putirka et al., 2003), and $0.75 \pm 0.15$ GPa (Putirka, 2008). Temperature estimates for sample PM 46 (B posII unit) range between $1173 \pm 27^{\circ} \mathrm{C}$ and $1179 \pm 27^{\circ} \mathrm{C}$ (Putirka et al., 1996), $1152 \pm 33^{\circ} \mathrm{C}$ (Putirka et al., 2003), and $1155 \pm 58^{\circ} \mathrm{C}$ (Putirka, 2008). For sample PY 13 ( $B$ posII unit), the estimated temperatures were in the range of $1149 \pm 27{ }^{\circ} \mathrm{C}$ and $1161 \pm 27{ }^{\circ} \mathrm{C}$ (Putirka et al., 1996), $1122 \pm 33^{\circ} \mathrm{C}$ (Putirka et al., 2003), and $1161 \pm 58{ }^{\circ} \mathrm{C}$ (Putirka, 2008). In the case of sample PY 5 ( $B$ pre unit), calculations gave temperatures between $1164 \pm 27{ }^{\circ} \mathrm{C}$ and $1176 \pm 27{ }^{\circ} \mathrm{C}$ (Putirka et al., 1996), $1135 \pm 33^{\circ} \mathrm{C}$ (Putirka et al., 2003), and $1166 \pm 58^{\circ} \mathrm{C}$ (Putirka, 2008).

Plagioclase-based thermometers did not give good results in the case of the basaltic lavas, since equilibrium conditions (i.e., $\mathrm{Kd}(\mathrm{An}-\mathrm{Ab})^{\mathrm{Pl}-\mathrm{Liq}}=0.27 \pm 0.05$ for T $>1050^{\circ} \mathrm{C}$, Putirka, 2008) are not archived. Only one pair of plagioclase-liquid of sample PY 13 (B posII unit) is close to equilibrium, with a $\mathrm{Kd}(\mathrm{An}-\mathrm{Ab})^{\mathrm{Pl}-\mathrm{Liq}}$ value of 0.21 . Temperature with this plagioclase-liquid composition pair and a priori pressure values in the range of $0.4-1.2 \mathrm{GPa}$ was estimated using the methods of Putirka (2005) and Putirka (2008). Estimated temperatures with this method are higher than the ones estimated with olivine-liquid and clinopyroxene-liquid compositions, and they are in the range of $1229 \pm 23^{\circ} \mathrm{C}$ and $1276 \pm 23^{\circ} \mathrm{C}$ (Putirka, 2005) and between $1192 \pm$ $36{ }^{\circ} \mathrm{C}$ and $1252 \pm 36{ }^{\circ} \mathrm{C}$ (Putirka, 2008).

\section{Discussion}

\subsection{Depths of magma stagnation}

Pressure estimation of pre- and post-caldera basaltic magmas using clinopyroxene-liquid equilibria (Putirka et al., 1996, 2003) lie in the range of $0.48-0.78 \mathrm{GPa}$. Crustal thickness in the Andean back-arc, interpreted from seismic velocities at $\sim 39^{\circ} \mathrm{S}$ ( $280 \mathrm{~km}$ south of PMVF), is around 30-35 km (Wagner et al., 2005; Yuan et al., 2006). Crustal depth in the PMVF area estimated from seismic and satellite gravimetric data is between 51 and $47 \mathrm{~km}, \pm 5 \mathrm{~km}$ (Reguzzoni et al., 2013), 

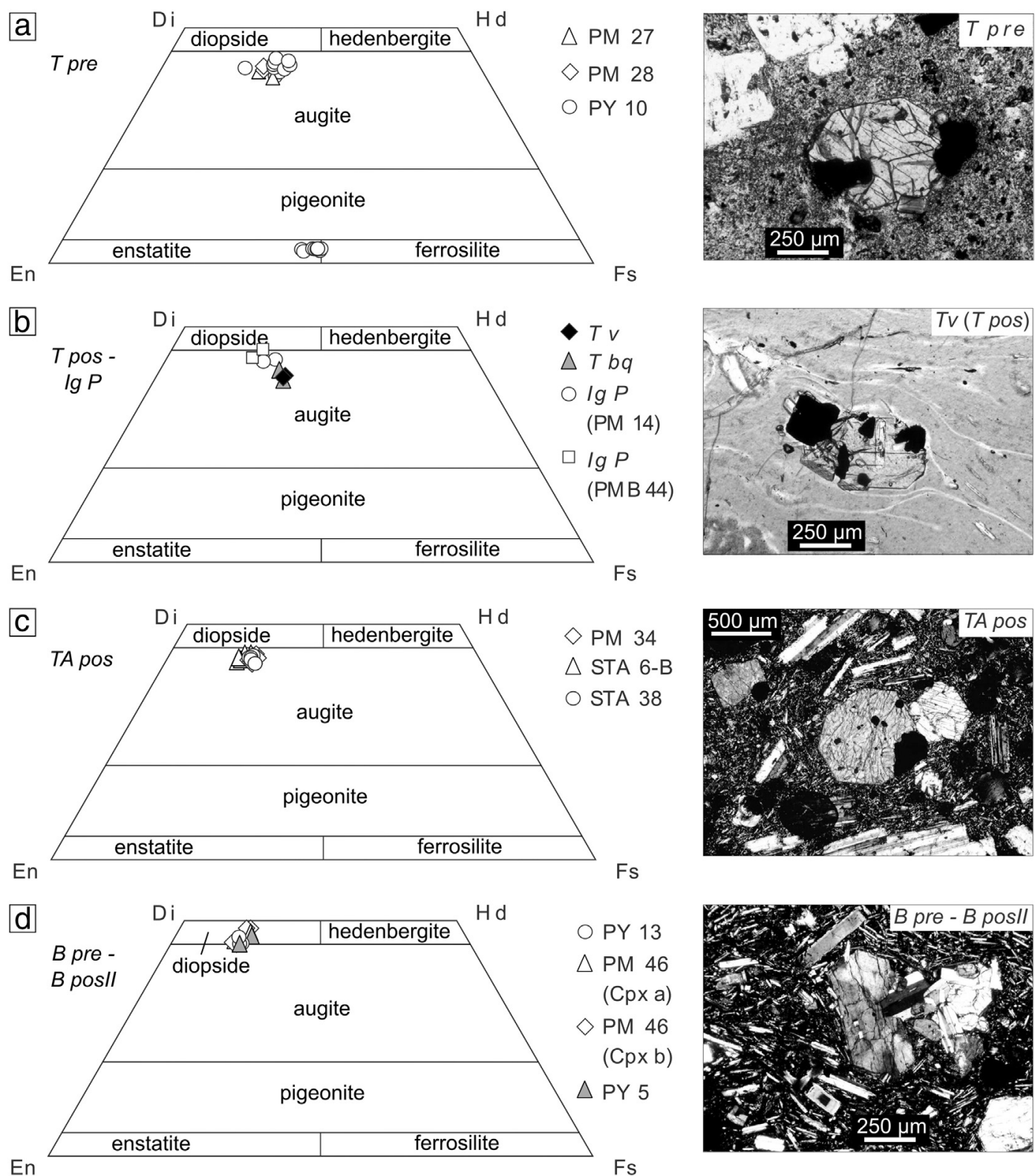

e

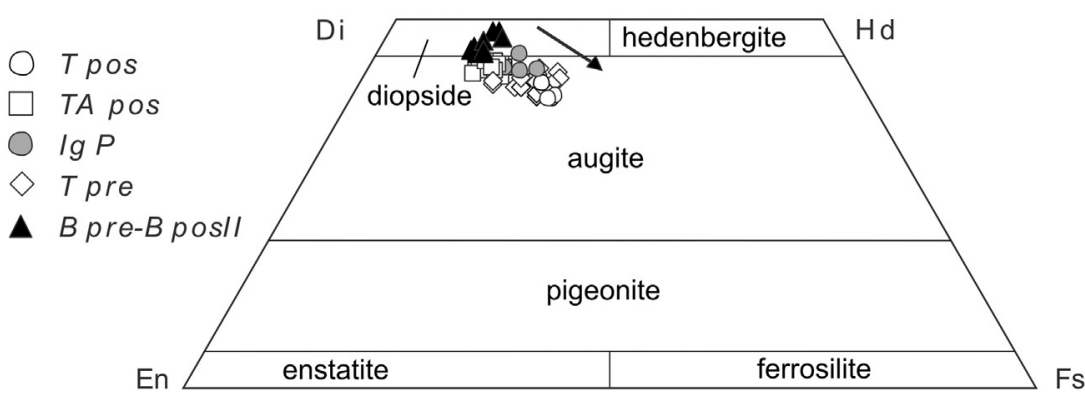

Fig. 11. Pyroxene compositions of PMVF rocks.

significantly thicker than the crust at $39^{\circ} \mathrm{S}$. There is no contradiction between both crustal models, as the crustal depth at $39^{\circ} \mathrm{S}$ in the back-arc area is $33-36 \mathrm{~km} \pm 4 \mathrm{~km}$ according with the Reguzzoni et al. (2013) model. Assuming a mean crustal density of $2.7 \mathrm{~g} / \mathrm{cm}^{3}$, the pressures estimates of the basaltic lavas correspond to a lithostatic load in the range of 18 and $29 \mathrm{~km}$. These depths are located in the middle crust, assuming a crustal depth as modeled by Reguzzoni et al. (2013).
In the case of the volcanic rocks of Payún Matrú caldera, the pressure estimation using clinopyroxene-liquid equilibria did not give reliable results. Therefore, a comparison of estimated pressures between the basaltic fields and the Payún Matrú rocks is not possible. Nevertheless, two lines of evidence suggest that the magma chamber/s of the Payún Matrú volcano were (are) at a higher crustal level. First, the presence of a caldera indicates a relatively shallow magma chamber (Lipman, 2000), at 
Table 5

Selected compositions of amphibole and biotite phenocrysts, and volcanic glass of PMVF rocks.

\begin{tabular}{|c|c|c|c|c|c|c|c|c|c|}
\hline \multicolumn{4}{|c|}{ Amphibole } & \multicolumn{3}{|l|}{ Biotite } & \multicolumn{3}{|c|}{ Volcanic glass } \\
\hline Unit & $\begin{array}{l}\text { TA } \\
\text { pos }\end{array}$ & T pre & T pre & Unit & T pre & T pre & Unit & $T v$ & $\operatorname{Ig} P$ \\
\hline Sample & $\begin{array}{l}\text { STA } \\
6 B\end{array}$ & $\begin{array}{l}\text { PM } \\
28\end{array}$ & $\begin{array}{l}\text { PY } \\
10\end{array}$ & Sample & $\begin{array}{l}\text { PM } \\
27\end{array}$ & $\begin{array}{l}\text { PY } \\
10\end{array}$ & Sample & $\begin{array}{l}\text { PMA } \\
27 \mathrm{~A}\end{array}$ & $\begin{array}{l}\text { PM } \\
14\end{array}$ \\
\hline$\%$ & & & & $\%$ & & & $\%$ & & \\
\hline $\mathrm{SiO}_{2}$ & 41.59 & 40.87 & 41.82 & $\mathrm{SiO}_{2}$ & 36.94 & 36.95 & $\mathrm{SiO}_{2}$ & 68.81 & 66.63 \\
\hline $\mathrm{TiO}_{2}$ & 5.36 & 4.28 & 4.68 & $\mathrm{TiO}_{2}$ & 7.32 & 6.54 & $\mathrm{TiO}_{2}$ & 0.37 & 0.40 \\
\hline $\mathrm{Al}_{2} \mathrm{O}_{3}$ & 11.96 & 12.54 & 12.10 & $\mathrm{Al}_{2} \mathrm{O}_{3}$ & 14.11 & 13.79 & $\mathrm{Al}_{2} \mathrm{O}_{3}$ & 15.73 & 16.56 \\
\hline $\mathrm{FeO}$ & 11.78 & 12.60 & 13.18 & $\mathrm{FeO}$ & 15.23 & 18.02 & $\mathrm{FeO}$ & 2.57 & 2.62 \\
\hline $\mathrm{MnO}$ & 0.16 & 0.17 & 0.27 & $\mathrm{MnO}$ & 0.20 & 0.30 & $\mathrm{MnO}$ & 0.09 & 0.09 \\
\hline $\mathrm{MgO}$ & 13.20 & 13.06 & 12.65 & $\mathrm{MgO}$ & 13.81 & 11.76 & $\mathrm{MgO}$ & 0.28 & 0.38 \\
\hline $\mathrm{CaO}$ & 11.01 & 10.82 & 10.83 & $\mathrm{CaO}$ & 0.05 & 0.00 & $\mathrm{CaO}$ & 0.57 & 0.82 \\
\hline $\mathrm{Na}_{2} \mathrm{O}$ & 2.64 & 2.75 & 2.68 & $\mathrm{Na}_{2} \mathrm{O}$ & 0.87 & 0.79 & $\mathrm{Na}_{2} \mathrm{O}$ & 3.58 & 3.88 \\
\hline $\mathrm{K}_{2} \mathrm{O}$ & 0.94 & 0.94 & 0.87 & $\mathrm{~K}_{2} \mathrm{O}$ & 8.77 & 8.83 & $\mathrm{~K}_{2} \mathrm{O}$ & 5.79 & 6.67 \\
\hline $\mathrm{F}$ & 0.06 & 0.00 & 0.00 & F & 0.25 & 0.10 & $\mathrm{~F}$ & 0.06 & 0.11 \\
\hline $\mathrm{Cl}$ & 0.00 & 0.02 & 0.01 & $\mathrm{Cl}$ & 0.06 & 0.14 & $\mathrm{Cl}$ & 0.35 & 0.22 \\
\hline $\mathrm{Cr}_{2} \mathrm{O}_{3}$ & 0.02 & 0.01 & 0.00 & $\mathrm{BaO}$ & 0.73 & 0.43 & & & \\
\hline Total & 98.61 & 98.05 & 99.09 & Total & 98.32 & 97.65 & Total & 98.19 & 98.35 \\
\hline
\end{tabular}

least in the syn- and post-caldera stages. Second, the trachytic magmas are a product of fractional crystallization of the basaltic magmas (Hernando et al., 2014a), and therefore the former could not stagnate at a deeper crustal level. The PMVF magmatic system is most probably formed by a relatively deep-seated basaltic reservoir and a shallower magma chamber which receives the magma supply from the deeper reservoir (a double-magma chamber, as in Gudmundsson, 2006). The basaltic fields located east and west of the Payún Matrú volcano were fed from the deeper magma chamber/s without the interference of the Payún Matrú evolved chamber/s.

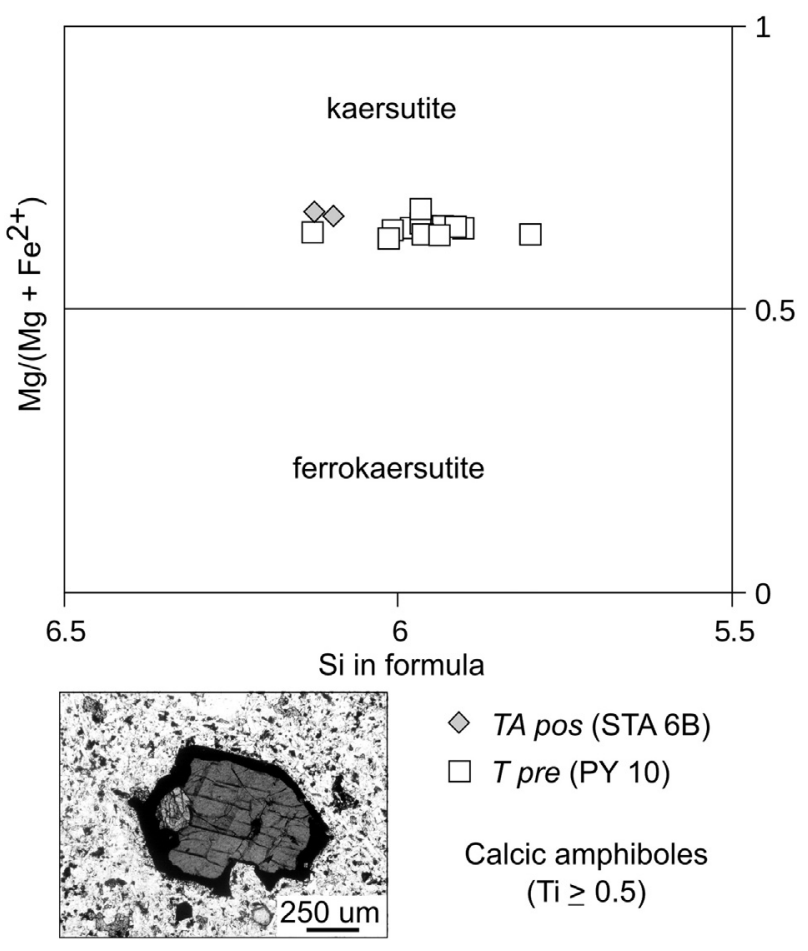

Fig. 12. Classification scheme of calcic amphiboles (Leake et al., 2004). The amphibole of sample PM 28 ( $T$ pre unit) presents a slightly lower Ti content $(\mathrm{Ti}=0.46-0.48$ per formula unit) and it is classified as pargasite or magnesiohastingsite, and therefore it is not shown in this diagram.

\subsection{Magma mixing and mingling}

As pointed out by Hernando et al. (2012, 2014a), many aspects of field relations, petrography, whole-rock geochemistry, and mineral compositions strongly suggest that the processes of magma mixing/ mingling were repeated in the evolution of the PMVF. The abundance of basaltic volcanism east and west of the Payún Matrú volcano is interrupted in the polygenetic volcanic edifice (Fig. 13). There are no basaltic lavas registered in the Payún Matrú volcano, and the most basic lavas are basaltic trachyandesites (Hernando et al., 2014a). Given the absence of basic lavas and that these lavas come from a relatively deeper reservoir than the ones of Payún Matrú, it is probable that the basaltic magmas have been trapped in the more silicic and shallower magma chamber/s of the Payún Matrú volcano on their way to the surface. In consequence, basaltic magmas would mix, mingle, or stagnate in the mostly trachytic magma chamber/s.

\subsubsection{Textural and mineralogical evidence for magma mixing and mingling}

In several T pre and TA pos units lavas of Payún Matrú, there are textural and mineralogical features that are interpreted as a result of magma mixing and mingling processes. These textures include lavas with euhedral to rounded sieved plagioclases (Fig. 5d; Tsuchiyama, 1985; Nakamura and Shimakita, 1998), some with a clear (non-sieved) rim of more calcic composition, and rounded feldspars with a diffuse interface with the groundmass (Tsuchiyama, 1985; Hibbard, 1981, 1995). Also, there are diverse mantled feldspars, like anti-rapakivi texture (Hibbard, 1981, 1995), rounded plagioclase cores with a more calcic rim (Stimac and Pearce, 1992) or a non-rounded plagioclase core with a significantly more sodic rim (Tsuchiyama, 1985). The biotite phenocrysts that show a replacement by anhydrous minerals suggest an up-grade of thermal conditions or replenishment of the magma chambers (Fig. 5b; Feeley and Sharp, 1996). These lavas show also reverse zoning in plagioclase and clinopyroxenes, which may be also a result of an increase in volatile content, although in the presence of other mixing textures, it is probable that mixing processes is the plausible explanation (Mandeville et al., 1996; Kusçu and Floyd, 2001; Andrews et al., 2008). Other disequilibrium textures include rounded minerals, which are common in clinopyroxenes of the PMVF (Vernon, 2004), and different groundmasses with sharp and fluidal boundaries between them (Fig. 5a). The contrasting textures and composition of plagioclase and mafic minerals found in the same thin section reflect different histories and therefore could not have formed together (Fig. 5d; Clynne, 1999; Murphy et al., 2000).

In the PMVF, there are also other disequilibrium textures, which are not interpreted as the result of magma mixing. These are (1) coarse sieved plagioclases, a result of adiabatic decompression (Nelson and Montana, 1992), the morphology of these plagioclase inclusions in $T$ pre and TA pos rocks are different from those reported by Halsor (1989) which are explained as a consequence of rapid growth due to magma mixing processes; (2) amphibole with a rim of opaque and anhydrous minerals and biotite with an opaque rim, formed by decompression and volatile loss (Fig. 12; Rutherford and Hill, 1993; Browne and Gardner, 2006); (3) patchy zoning in feldspars, formed by dissolution of the crystal core by decompression, followed by crystallization of feldspar in equilibrium with the new conditions (Vernon, 2004); (4) embayed and non-rounded olivine phenocrysts (formed by crystal growth in equilibrium, Faure and Schiano, 2005); (5) feldspars with relatively large holes which are controlled by its crystal structure (skeletal growth, Lofgren, 1974).

\subsubsection{End-member compositions}

The geochemistry of the rocks from Payún Matrú is in accordance with the magma mixing/mingling processes which were identified by petrographic analyses (Hernando et al., 2014a). The whole-rock chemical analyses are useful for the estimation of the end-members magma compositions. In element-element plots, hybrid magmas plot on a straight line between the end-members compositions (Langmuir et al., 
Table 6

Results of the thermobarometric estimations for PMVF rocks.

\begin{tabular}{|c|c|c|c|c|c|}
\hline Unit & Sample & $\mathrm{P}(\mathrm{GPa})$ & Temperature $\left({ }^{\circ} \mathrm{C}\right)$ & Method & \\
\hline \multirow[t]{5}{*}{ B posII } & PM 46 & $0.4-1.2$ (a priori) & $1179-1221$ & Ol - Liq & Beattie (1993) \\
\hline & & $0.4-1.2$ (a priori) & $1174-1216$ & Ol - Liq & Putirka et al. (2007) \\
\hline & & 0.55 & $1173-1179$ & Cpx - Liq & Putirka et al. (1996) \\
\hline & & 0.5 & 1152 & Cpx - Liq & Putirka et al. (2003) \\
\hline & & 0.78 & 1155 & Cpx - Liq & Putirka (2008) \\
\hline \multirow[t]{5}{*}{ B posII } & PY 13 & 0.57 & 1149-1161 & Cpx - Liq & Putirka et al. (1996) \\
\hline & & 0.48 & 1122 & Cpx - Liq & Putirka et al. (2003) \\
\hline & & 0.57 & 1161 & Cpx - Liq & Putirka (2008) \\
\hline & & $0.4-1.2$ (a priori) & $1229-1276$ & Pl - Liq & Putirka (2005) \\
\hline & & $0.4-1.2$ (a priori) & $1192-1252$ & Pl - Liq & Putirka (2008) \\
\hline \multirow[t]{5}{*}{ B pre } & PY 5 & $0.4-1.2$ (a priori) & $1157-1198$ & Ol - Liq & Beattie (1993) \\
\hline & & $0.4-1.2$ (a priori) & $1143-1185$ & Ol - Liq & Putirka et al. (2007) \\
\hline & & 0.67 & $1164-1176$ & Cpx - Liq & Putirka et al. (1996) \\
\hline & & 0.59 & 1135 & Cpx - Liq & Putirka et al. (2003) \\
\hline & & 0.75 & 1166 & Cpx - Liq & Putirka (2008) \\
\hline \multirow[t]{4}{*}{$T v(T$ pos $)$} & PMA 27 A & - & 1001 & Glass & Putirka (2008) Eq. (13) \\
\hline & & - & 955 & Glass & Putirka (2008) Eq. (14) \\
\hline & & $0.01-0.4$ (a priori) & $930-950$ & Ol - Liq & Putirka et al. (2007) \\
\hline & & $0.01-0.4$ (a priori) & 866 & Af - Liq & Putirka (2008) \\
\hline$T b q(T p o s)$ & PM 40 & $0.01-0.4$ (a priori) & $863-865$ & Af - Liq & Putirka (2008) \\
\hline \multirow[t]{4}{*}{$\lg P$} & PM 14 & - & 1004 & Glass & Putirka (2008) Eq. (13) \\
\hline & & - & 984 & Glass & Putirka (2008) Eq. (14) \\
\hline & & $0.01-0.4$ (a priori) & $933-953$ & Ol - Liq & Putirka et al. (2007) \\
\hline & & $0.01-0.4$ (a priori) & $947-951$ & Af - Liq & Putirka (2008) \\
\hline
\end{tabular}

1978). Fig. 14 shows the Harker diagrams for $\mathrm{Al}_{2} \mathrm{O}_{3}$ and $\mathrm{CaO}$, in which the lavas of the basaltic fields and the most silicic trachytes ( $T$ pos unit and some of the $T$ pre unit lavas) are grouped in circles. The samples of $T$ pre and TA pos lavas which present the mixing/mingling evidence mentioned are shown in Fig. 14. In the $\mathrm{CaO}$ diagram, the rocks of Payún Matrú with an intermediate silica content and mixing/mingling textures lie mostly inside the mixing trend between basalts/ trachybasalts and the most silicic trachytes, but this is not the case in the $\mathrm{Al}_{2} \mathrm{O}_{3}$ diagram (Fig. 14). Therefore, the most silicic trachytes cannot be the silicic end-member. In addition, the predominant phenocryst in the hybrid magmas is plagioclase, and not alkali feldspar such as those present in the most silicic trachytes. If most of the TA pos lavas and some of the $T$ pre lavas are hybrid/mingled lavas, the silicic endmember would be a trachyte of an intermediate silica content (e.g., a trachyte of similar composition of the Portezuelo Ignimbrite).

\subsubsection{Hybridization vs. mafic enclaves}

When two or more magmas of different composition are in contact with each other, the degree of homogenization may be variable. In addition to the composition of the magmas involved, other factors influence the mixing extent, such as the volatile content, the viscosity and temperature contrasts, the degree of crystallinity, the relative proportion of mafic magma, the degree of turbulence in the injection, and the size of the injection (Sparks and Marshall, 1986; Campbell and Turner, 1986; Andrews and Manga, 2014). Rounded or irregular mafic enclaves found in intermediate to acidic lavas are interpreted as a clear evidence for magma mingling (Eichelberger, 1980; Bacon, 1986; Murphy et al., 2000; Coombs et al., 2002, among others). Enclave formation is favored when temperature and viscosity contrasts between the host and injected magmas are high, when the proportion of mafic magma in comparison with the more silicic magma is low, and when the size of

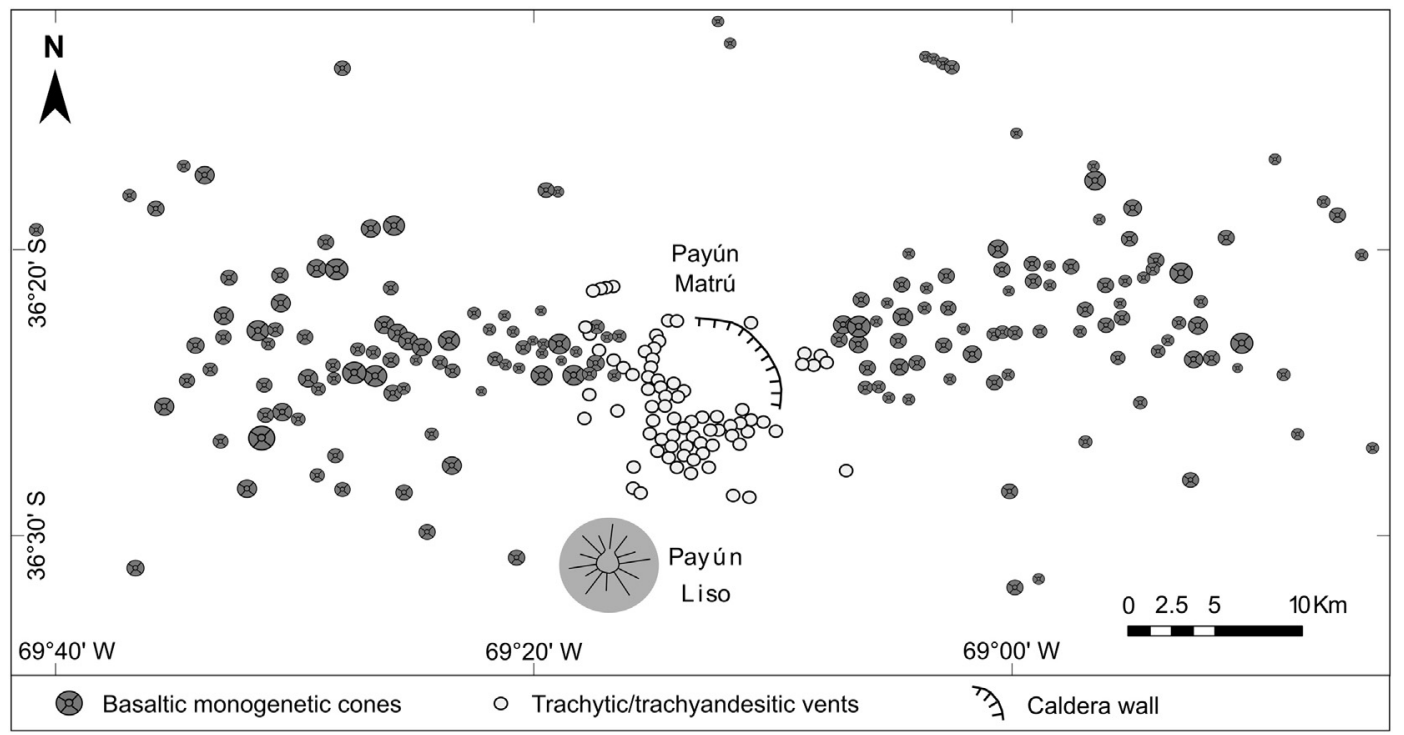

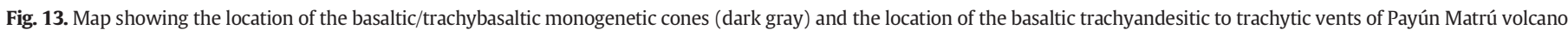
(light gray). The location of all vents is available in Supplementary File 1. 

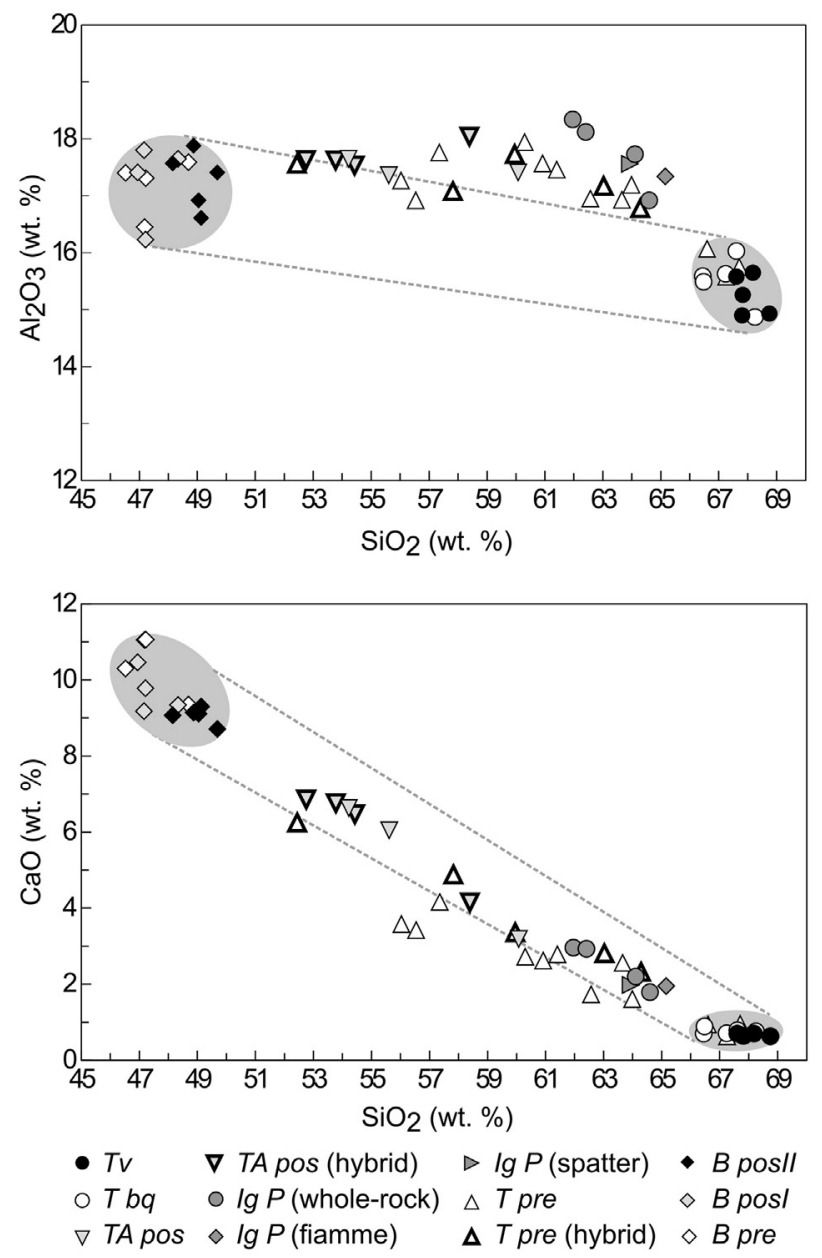

Fig. 14. Harker diagrams for $\mathrm{Al}_{2} \mathrm{O}_{3}$ and $\mathrm{CaO}$, showing in grey circles the lavas of the basaltic fields and the most silicic trachytes ( $T$ pos unit and some $T$ pre unit samples). The lavas with mixing or mingling textures lie mostly outside the trend that connect the basaltic/ trachybasaltic lavas with the most silicic trachytes (in the $\mathrm{Al}_{2} \mathrm{O}_{3}$ diagram), and therefore the most silicic trachytes could not represent the silicic end-member of the mixing for these samples. Modified from Hernando et al. (2014a).

the injection is small (Campbell and Turner, 1986; Sparks and Marshall, 1986; Andrews and Manga, 2014).

Hybridization can take place if, after the thermal equilibration, the more mafic magma remains fluid enough, which typically requires a great proportion of the more mafic magma (nearly 50\%) or that the more mafic magma is not basaltic but of an intermediate composition (Sparks and Marshall, 1986). Also, the hybridization between magmas of different composition may be due to the disintegration of previously formed enclaves (Clynne, 1999).

Mafic enclaves in Payún Matrú rocks are rare (Hernando et al., 2012). More frequently, mingling evidence is found in some lavas having two different groundmass with fluidal contacts (Hernando et al., 2012), which suggests an intermediate situation between enclave formation and complete hybridization. Evidence for hybrid magmas is far more common than mingling processes in the PMVF (Hernando et al., 2012).

The proportions of basic and silicic magmas involved in the mixing processes can be calculated using least square approximations (Bryan et al., 1969). Trachytic lavas with textural and compositional characteristics which suggest magma mixing in the pre-caldera stage of the Payún Matrú volcano are shown in Fig. 14. The proportion of mafic magmas in these cases is low, less than $17 \%$. Given the absence of inclusions in these lavas, it is probable that these lavas are a result of multiple mixing events, mixing trachytic and intermediate hybrid magmas, which would enhance the homogenization between the magmas involved (due to the lesser thermal, compositional and viscosity contrasts). A similar situation represents one lava of the Post-caldera Trachyandesites unit (sample STA 6B; Fig. 14), in which the proportion of basaltic magma is $22 \%$. In some intermediate $T$ pre lavas and in most TA pos lavas $\left(\mathrm{SiO}_{2}<55 \%\right.$ ), the hybridization is favored by the high proportion of basaltic magma involved, between 49 and $66 \%$.

The estimated temperatures can be used to infer the possible thermal contrasts between the interacting magmas. An approximation to the temperature contrasts between the end-members mixed can be made, assuming a basaltic end-member and a trachyte with intermediate silica content. Since the samples of the $T$ pre and TA pos units with available mineral compositions present evidence of hybridization, these samples cannot be used to thermometric estimations, and would not represent the silicic end-member of the mixing. Also, as inferred from whole-rock compositions, the felsic end-member is not represented by a trachyte such as those of the $T$ pos unit and, therefore, the temperature estimations for this unit is not used as representative of the silicic end-member. For the basaltic end-member, the estimated temperatures lie in a wide range, between $1122 \pm 33{ }^{\circ} \mathrm{C}$ and $1276 \pm$ $23{ }^{\circ} \mathrm{C}$ with the samples of Pre- and Post-caldera Basalts II units. Assuming a silicic end-member of temperature and composition similar to the Portezuelo Ignimbrite (sample PM 14), the estimated temperature would be between $863 \pm 23{ }^{\circ} \mathrm{C}$ and $1004 \pm 71{ }^{\circ} \mathrm{C}$. Thus, according with these estimations, temperature contrast between the two endmembers mixed may be as high as $413^{\circ} \mathrm{C}$ and as low as $118^{\circ} \mathrm{C}$.

On the other hand, the scarcity of mafic enclaves could be the result of several factors, such as the high proportion of mafic magma, the possible low thermal contrast between the involved magmas, and multiple events of mixing which reduced the thermal and viscosity contrasts, resulting in the mixing of trachytic and intermediate magmas, in addition to enclave disruption.

\subsection{Caldera-forming eruptions and their trigger}

The trigger mechanism for caldera-forming eruptions may be related to internal (magmatic) processes, or may be due to an external cause (de Silva and Gregg, 2014). Much of the Andean collapse calderas are compositionally homogeneous, especially those present in the Central Volcanic Zone (CVZ, $14^{\circ}-28^{\circ} \mathrm{S}$ ). The CVZ calderas have been formed in general by a unique collapse episode (Lindsay et al., 2001; Kay et al., 2011), although some CVZ calderas have more than one event of collapse superimposed, constituting caldera complexes (Petrinovic et al., 2010). Conspicuously, the different cycles in caldera complexes are compositionally homogeneous (dacitic and rhyodacitic) and characterized by major eruptions ending each cycle with resurgent stages (Lindsay et al., 2001; Petrinovic et al., 2010). Overpressure in the overlying roof in major magma chambers has been proposed as the trigger mechanism to cause super eruptions in collapse calderas (Gregg et al., 2012). In addition, the magma reservoirs which feed these major eruptions accumulate magma in long periods of time (0.1-1 Ma) and are triggered by root uplift (de Silva and Gregg, 2014) or by tectonics (Riller et al., 2001; Lindsay et al., 2001; Aguirre-Díaz et al., 2008).

On the other hand, the classical collapse calderas of the Southern Volcanic Zone (SVZ) show a lesser volume of the collapse-related deposits (less or around $100 \mathrm{~km}^{3}$ ), a minor diameter of the collapsed area (commonly $<20 \mathrm{~km}$ ), a wide range of compositions exposed in the same cycle (in some calderas), and alternation of effusiveexplosive episodes. Examples of these SVZ calderas are the Caviahue caldera (Mazzoni and Licitra, 2000; Varekamp et al., 2006), the Diamante caldera (Sruoga et al., 2012), and the Payún Matrú caldera (Hernando et al., 2012, 2014a). Magma reservoirs associated with these calderas are not homogeneous; disequilibrium textures and/or contrasting mineral compositions are common. These differences between SVZ and CVZ calderas suggest that the trigger mechanism of 
roof uplift is not effective in the relatively small reservoirs of the SVZ calderas, and thus these calderas need another trigger mechanism, such as recharge or tectonics (Gregg et al., 2013).

\subsubsection{The eruption trigger for the Portezuelo Ignimbrite}

A widely accepted trigger mechanism for an explosive eruption is the injection of basaltic magma into a silicic magma chamber (Pallister et al., 1992; Mandeville et al., 1996; Snyder, 2000; Aguirre-Díaz, 2001; Leonard et al., 2002, among others). Considering the distribution of the volcanic centers in the PMVF and the textural and compositional evidence of mixing/mingling in the pre-caldera stage, it would be expected that the injection of a deep-seated mafic magma in the relatively shallow Payún Matrú magma chamber resulted in the eruption of the
Portezuelo Ignimbrite. Nevertheless, the Portezuelo Ignimbrite does not have textural evidence of hybridization like some Pre-caldera Trachytes and Post-caldera Trachyandesites lavas. The Portezuelo Ignimbrite presents crystals with dissolution textures, such as sieved and rounded crystals and biotite partially replaced by anhydrous minerals, which may be explained by an increase in temperature of the magma (Tsuchiyama, 1985; Feeley and Sharp, 1996; Nakamura and Shimakita, 1998). These crystals with disequilibrium textures are a minority compared to those non-reacted, suggesting that only a minor proportion of the magma was heated.

Snyder (2000) modeled the thermal effects produced by an injection of a basaltic magma at the bottom of a more silicic magma chamber. The basaltic magma may form a mafic layer at the bottom of the chamber,

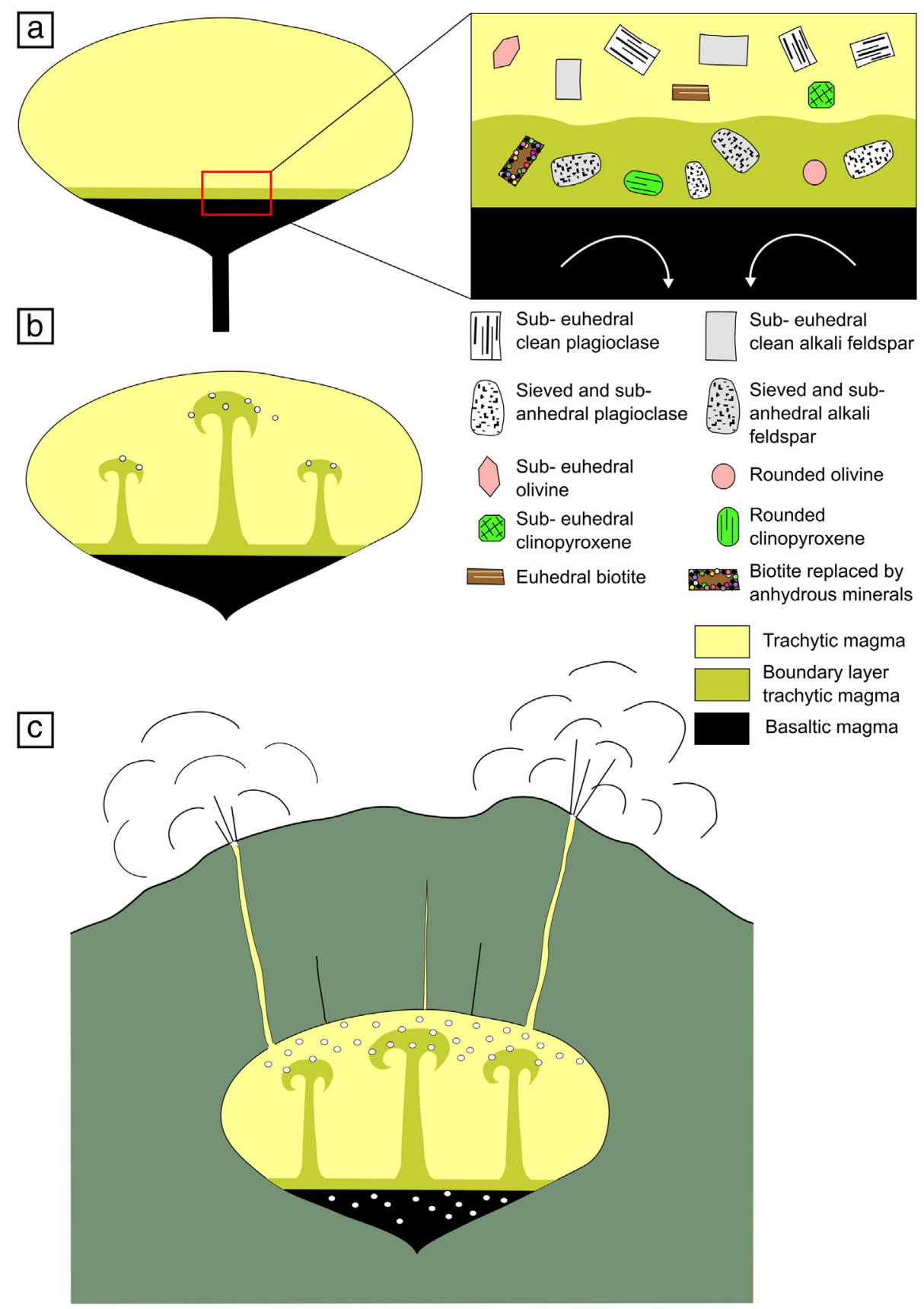

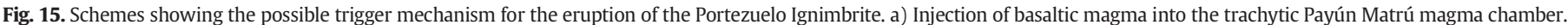

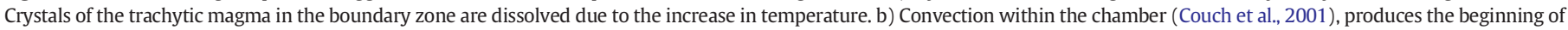

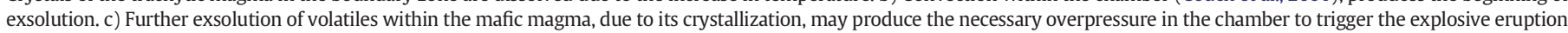
(Folch and Martí, 1998). 
especially if the magma input is slow (Turner and Campbell, 1986). The thermal and compositional contrasts between both magmas produce convection cells in both layers (Snyder, 2000; Couch et al., 2001). Convection in the host trachytic magma of the Payún Matrú chamber may have been possible due to the relatively low crystal content $(<30 \%)$, which allowed it to behave as a fluid. A boundary layer is present at the base of the silicic magma layer in contact with the hotter basaltic magma, with high thermal and viscosity gradients, that may be only 1-2 m in thickness (Snyder, 2000; Couch et al., 2001). Crystals of the silicic magma present in this boundary layer may be reabsorbed due to the increase in temperature. The mafic layer is over-cooled and enhances its crystallization, and eventually the exsolution of volatiles occurs (Eichelberger, 1980; Folch and Martí, 1998). The time required for the complete thermal homogenization in the silicic magma (a few years to dozens of years for each meter of thickness of the silicic magma layer; Snyder, 2000) may be large in comparison with the time between the injection of the hotter magma and the eruption (days to a few months; Folch and Martí, 1998). Therefore, thermal homogenization before eruption of the silicic magma may not be reached, and the thickness of silicic magma which increases its temperature is basically the boundary layer in contact with the mafic magma. The convection in the silicic magma due to the thermal gradient may produce the mixing of the reabsorbed crystals with the non-reacted ones (Couch et al., 2001), thereby producing a mixed crystal population in the erupted products.

The lack of mafic enclaves and hybridization evidence in the Portezuelo Ignimbrite suggest that convection in the magma chamber was not vigorous enough as to effectively mix both magmas. Therefore, the heat exchange between the hotter mafic magma and the silicic magma was not as efficient as would be in the case of complete mixing (Ruprecht and Bachmann, 2010). The presence of a minority of crystals with dissolution textures in the Portezuelo Ignimbrite also suggest that heating of the trachytic magma was restricted to a small fraction of the chamber. The mechanism of self-mixing in a convective magma chamber may produce the diversity of mineralogical textures found in the eruptive products (Couch et al., 2001). The most plausible cause for this temperature increase would be an injection of basaltic (or more mafic) magma into the Payún Matrú trachytic magma chamber. Thus, the eruption of the Portezuelo Ignimbrite may have been triggered by an injection of a hotter mafic (probably basaltic) magma at the bottom of the trachytic Payún Matrú magma chamber (Fig. 15). The necessary overpressure to trigger the eruption is reached not only by the increase in volume due to the magma injection into the chamber and by vesiculation of the felsic magma, but also by volatile exsolution of the mafic layer, which is a more effective mechanism to increase the chamber pressure (Folch and Martí, 1998).

No evidence of the basaltic magma has been found in the eruption products which form the Portezuelo Ignimbrite. The post-caldera stage began with the effusion of intermediate lavas (basaltic trachyandesites to trachyandesites) with mixing and mingling evidence. These lava flows may represent the lowermost part of the reservoir, which erupted after the caldera-forming eruption, as occurred in other calderas (e.g. Ksudach volcano, Kamchatka, Braitseva et al., 1996).

If mafic recharge triggers eruptions and magma mixing processes were relatively common in the PMVF, a question arises as why the Portezuelo Ignimbrite is the only record (so far) of an explosive eruption triggered by this mechanism in this volcanic field. The nonhybridization between trachytic and more mafic magmas would not produce an effective heat exchange between both magmas, and thus the decrease in the host trachytic magma viscosity would not be significant (Ruprecht and Bachmann, 2010). This, in turn, does not enhance syneruptive degassing, favoring the explosive eruptive behavior of the caldera-forming eruption. On the other hand, the complete hybridization between mafic and silicic magmas facilitate significant reheating of the silicic magma, thereby reducing its viscosity and promoting the syneruptive degassing and the effusive behavior of the eruption
(Ruprecht and Bachmann, 2010). This may explain why the evidence of hybridization in the PMVF are found in lava flows and not in pyroclastic deposits.

\section{Conclusions}

Some pre-caldera and post-caldera lavas of Payún Matrú preserve textural and mineralogical disequilibrium features which may be explained by magma mixing between basaltic/trachybasaltic and trachytic magmas. The proportion of mafic magmas in the mixing is high in the case of intermediate hybrid lavas, while it is low in the more hybrid silicic lavas, suggesting more complex processes and multiple mixing events. Mingling evidence in Payún Matrú lavas are far less common than complete mixing evidence. The silicic end-member of the mixing would be a trachyte of intermediate silica content, and not the most silicic ones. The youngest lavas and pyroclastic deposits of the postcaldera stage of Payún Matrú do not show compositional or textural evidence of mixing/mingling with basic magmas.

Temperature estimates for the basaltic and trachybasaltic magmas are between $1122^{\circ}$ and $1276{ }^{\circ} \mathrm{C}$, and pressure estimates lie between $0.48-0.78 \mathrm{GPa}$ (equivalent to a lithostatic load of $18-29 \mathrm{~km}$ of crust, assuming a mean crustal density of $2.7 \mathrm{~g} / \mathrm{cm}^{3}$ ). Temperature estimates of the syn-caldera and post-caldera trachytic magmas of Payún Matrú are $863^{\circ}-1004^{\circ} \mathrm{C}$.

The trigger mechanism for the caldera-forming eruption of the Portezuelo Ignimbrite may have been a more mafic magma input into the trachytic chamber of the Payún Matrú volcano. The incomplete mixing between the mafic and hotter magma and the trachytic magma would have favored the explosive nature of the eruption, instead of an effusive character.

\section{Acknowledgments}

We would like to thank the staff of Recursos Naturales Renovables of Malargüe, Mendoza province, Argentina, for their help in during the field works. This work was supported by Universidad Nacional de La Plata grants [N547, N620] to Eduardo J. Llambías and a Consejo Nacional de Investigaciones Científicas y Técnicas grant [PIP 112-200801-00119] to Ana María Sato. Reviews by G. Aguirre-Díaz and B. Andrews helped to improve the original manuscript.

\section{Appendix A. Supplementary data}

Supplementary data associated with this article can be found in the online version, at doi:http://dx.doi.org/10.1016/j.jvolgeores.2016.01. 008. These data include the Google map of the most important areas described in this article.

\section{References}

Aguirre-Díaz, G.J., 2001. Recurrent magma mingling in successive ignimbrites from Amealco caldera, Central Mexico. Bull. Volcanol. 63, 238-251.

Aguirre-Díaz, G.J., Labarthe-Hernández, G., Tristán-González, M., Nieto-Obregón, J., Gutierrez-Palomares, I., 2008. The ignimbrite flare-up and graben calderas of the Sierra Madre Occidental, Mexico. In: Gottsmann, J., Martí, J. (Eds.), Caldera volcanism: Analysis, modelling and responseDevelopments in Volcanology 10. Elsevier, Amsterdam, pp. 143-180.

Andrews, B.J., Manga, M., 2014. Thermal and rheological controls on the formation of mafic enclaves or banded pumice. Contrib. Mineral. Petrol. 167, 961.

Andrews, B.J., Gardner, J.E., Housh, T.B., 2008. Repeated recharge, assimilation, and hybridization in magmas erupted from El Chichón as recorded by plagioclase and amphibole phenocrysts. J. Volcanol. Geotherm. Res. 175, 415-426.

Bacon, C.R., 1986. Magmatic inclusions in silicic and intermediate volcanic rocks. J. Geophys. Res. 91, 6091-6112.

Bastin, G.F., Heijligers, H.J.M., 1990. Progress in electron-probe microanalysis. Mater. Werkst. 21, 90-92.

Beattie, P., 1993. Olivine-melt and orthopyroxene-melt equilibria. Contrib. Mineral. Petrol. $115,103-111$.

Bermúdez, A., Delpino, D., 1989. La provincia basáltica andino cuyana. Rev. Asoc. Geol. Argent. 44 (1-4), 35-55. 
Bermúdez, A., Delpino, D., Frey, F., Saal, A., 1993. Los basaltos de retroarco extraandinos. In: Ramos, V.A. (Ed.), Congreso Geológico Argentino $\mathrm{N}^{\circ} 12$ and Congreso de Exploración de Hidrocarburos, Geología y Recursos Naturales de Mendoza, Relatorio I (13), Mendoza, pp. 161-172.

Braitseva, O.A., Melekestsev, I.V., Ponomareva, V.V., Kirianov, V.Yu., 1996. The caldera-forming eruption of Ksudach volcano about cal. A.D. 240: the greatest explosive event of our era in Kamchatka, Russia. J. Volcanol. Geotherm. Res. 70, 49-65.

Browne, B.L., Gardner, J.E., 2006. The influence of magma ascent path on the texture, mineralogy and formation of hornblende reaction rims. Earth Planet. Sci. Lett. 246, 161-176.

Bryan, W.B., Finger, L.W., Chayes, F., 1969. Estimating proportions in petrographic mixing equations by least square approximation. Science 163 (3870), 926-927.

Campbell, I.H., Turner, J.S., 1986. The influence of viscosity on fountains in magma chambers. J. Petrol. 27, 1-30.

Clynne, M.A., 1999. A complex magma origin for rocks erupted in 1915, Lassen Peak, California. J. Petrol. 40, 105-132.

Coombs, M.L., Eichelberger, J.C., Rutherford, M.J., 2002. Experimental and textural constraints on mafic enclave formation in volcanic rocks. J. Volcanol. Geotherm. Res. 119, 125-144.

Couch, S., Sparks, R.S.J., Carroll, M.R., 2001. Mineral disequilibrium in lavas explained by convective self-mixing in open magma chambers. Nature 411, 1037-1039.

de Silva, S.L., Gregg, P.M., 2014. Thermomechanical feedbacks in magmatic systems: implications for growth, longevity, and evolution of large caldera-forming magma reservoirs and their supereruptions. J. Volcanol. Geotherm. Res. 282, 77-91.

Eichelberger, J.C., 1980. Vesiculation of mafic magma during replenishment of silicic magma reservoirs. Nature 288, 446-450.

Espanon, V.R., Honda, M., Chivas, A.R., 2014a. Cosmogenic ${ }^{3} \mathrm{He}$ and ${ }^{21} \mathrm{Ne}$ surface exposure dating of young basalts from Southern Mendoza, Argentina. Quat. Geochronol. 19, 76-86.

Espanon, V.R., Chivas, A.R., Kinsley, L.P.J., Dosseto, A., 2014b. Geochemical variations in the Quaternary Andean back-arc volcanism, Southern Mendoza, Argentina. Lithos 208209, 251-264.

Faure, F., Schiano, P., 2005. Experimental investigation of equilibration conditions during forsterite growth and melt inclusion formation. Earth Planet. Sci. Lett. 236 (3-4) 882-898.

Feeley, T.C., Sharp, Z.D., 1996. Chemical and hydrogen isotopic evidence for in situ dehydrogenation of biotite in silicic magma chamber. Geology 24, 1021-1024.

Folch, A., Martí, J., 1998. The generation of overpressure in felsic magma chambers by replenishment. Earth Planet. Sci. Lett. 163, 301-314.

Folguera, A., Naranjo, J.A., Orihashi, Y., Sumino, H., Nagao, K., 2009. Retroarc volcanism in the northern San Rafael Block ( $34^{\circ}-35^{\circ} 30^{\prime}$ S), southern Central Andes: occurrence, age, and tectonic setting. J. Volcanol. Geotherm. Res. 186, 169-185.

Germa, A., Quidelleur, X., Gillot, P.Y., Tchilinguirian, P., 2010. Volcanic evolution of the back-arc Pleistocene Payun Matru volcanic field (Argentina). J. S. Am. Earth Sci. 29, 717-730.

Gregg, P.M., de Silva, S.L., Grosfils, E.B., Parmigiani, J.P., 2012. Catastrophic caldera-forming eruptions: thermomechanics and implications for eruption triggering and maximum caldera dimensions on earth. J. Volcanol. Geotherm. Res. 241-242, 1-12.

Gregg, P.M., de Silva, S.L., Grosfils, E.B., 2013. Thermomechanics of shallow magma chamber pressurization: implications for the assessment of ground deformation data at active volcanoes. Earth Planet. Sci. Lett. 384, 100-108.

Gudmundsson, A., 2006. How local stresses control magma-chamber ruptures, dyke injections, and eruptions in composite volcanoes. Earth Sci. Rev. 79, 1-31.

Gudnason, J., Holm, P.M., Søager, N., Llambías, E.J., 2012. Geochronology of the late Pliocene to recent volcanic activity in the Payenia back-arc volcanic province, Mendoza Argentina. J. S. Am. Earth Sci. 37, 191-201.

Halsor, S.P., 1989. Large glass inclusions in plagioclase phenocrysts and their bearing on the origin of mixed andesitic lavas at Tolimán volcano, Guatemala. Bull. Volcanol. 51, 271-280

Helz, R.T., Thornber, C.R., 1987. Geothermometry of Kilauea Iki lava lake, Hawaii. Bull. Volcanol. 49, 651-668.

Hernando, I.R., Llambías, E.J., González, P.D., Sato, K., 2012. Volcanic stratigraphy and evidence of magma mixing in the Quaternary Payún Matrú volcano, andean backarc in Western Argentina. Andean Geol. 39 (1), 158-179.

Hernando, I.R., Aragón, E., Frei, R., González, P.D., Spakman, W., 2014a. Constraints on the origin and evolution of magmas in the Payún Matrú Volcanic Field, Quaternary andean back-arc of Western Argentina. J. Petrol. 55 (1), 209-239.

Hernando, I.R., Franzese, J.R., Llambías, E.J., Petrinovic, I.A., 2014b. Vent distribution in the Quaternary Payún Matrú volcanic field, Western Argentina: its relation to tectonics and crustal structures. Tectonophysics 622, 122-134.

Hibbard, M.J., 1981. The magma mixing origin of mantled feldspars. Contrib. Mineral. Petrol. 76, 158-170.

Hibbard, M.J., 1995. Petrography to Petrogenesis. Prentice Hall, New Jersey.

Inbar, M., Risso, C., 2001. A morphological and morphometric analysis of a high density cinder cone volcanic field-Payún Matrú, south-central Andes, Argentina. Z. Geomorfologie 45 (3), 321-343.

Kay, S.M., Burns, W.M., Copeland, P., Mancilla, O., 2006. Upper Cretaceous to Holocene magmatism and evidence for transient Miocene shallowing of the Andean subduction zone under the northern Neuquén Basin. In: Kay, S.M., Ramos, V.A. (Eds.), Evolution of an Andean Margin: A Tectonic and Magmatic View from the Andes to the Neuquén Basin $\left(35^{\circ}-39^{\circ} \mathrm{S}\right.$ Latitude). Geological Society of America Special Paper 407, pp. 19-60 Colorado.

Kay, S.M., Coira, B., Wörner, G., Kay, R.W., Singer, B.S., 2011. Geochemical, isotopic and single crystal ${ }^{40} \mathrm{Ar} /{ }^{39} \mathrm{Ar}$ age constraints on the evolution of the Cerro Galán ignimbrites. Bull. Volcanol. 73, 1487-1511.
Kay, S.M., Jones, H.A., Kay, R.W., 2013. Origin of tertiary to recent EM- and subduction-like chemical and isotopic signatures in Auca Mahuida region $\left(37^{\circ}-38^{\circ} \mathrm{S}\right)$ and other Patagonian plateau lavas. Contrib. Mineral. Petrol. 166, 165-192.

Kusçu, G.G., Floyd, P.A., 2001. Mineral compositional and textural evidence for magma mingling in the Saraykent volcanics. Lithos 56, 207-230.

Langmuir, C.H., Vocke Jr., R.D., Hanson, G.N., Hart, S.R., 1978. A general mixing equation with applications to Icelandic basalts. Earth Planet. Sci. Lett. 37, 380-392.

Leake, B.E., Woolley, A.R., Arps, C.E.S., Birch, W.D., Gilbert, M.C., Grice, J.D., Hawthorn, F.C Kato, A., Kisch, H.J., Krivovichev, V.G., Linthout, K., Laird, J., Mandarino, J.A., Maresh, W.V., Nickel, E.H., Schumacher, J.C., Smith, D.C., Stephenson, N.C.N., Ungaretti, L., Whittaker, E.J.W., Youzhi, G., 1997. Nomenclature of amphiboles: report of the subcommittee on amphiboles of the International Mineralogical Association, commission on new minerals and mineral names. Can. Mineral. 35, 219-246.

Leake, B.E., Woolley, A.R., Birch, W.D., Burke, E.A.J., Ferraris, G., Grice, J.D., Hawthorn, F.C., Kisch, H.J., Krivovichev, V.G., Schumacher, J.C., Stephenson, N.C.N., Whittaker, E.J.W., 2004. Nomenclature of amphiboles: additions and revisions to the International Mineralogical Association's amphibole nomenclature. Am. Mineral. 89, 883-887.

Leonard, G.S., Cole, J.W., Nairn, I.A., Self, S., 2002. Basalt triggering of the c. AD 1305 Kaharoa rhyolite eruption, Tarawera volcanic complex, New Zealand. J. Volcanol. Geotherm. Res. 115 (3-4), 461-486.

Lindsay, J.M., de Silva, S., Trumbull, R., Emmermann, R., Wemmer, K., 2001. La Pacana caldera, N. Chile: a re-evaluation of the stratigraphy and volcanology of one of the world's largest resurgent calderas. J. Volcanol. Geotherm. Res. 106, 145-173.

Lipman, P.W., 2000. Calderas. In: Sigurdsson, H. (Ed.), Encyclopedia of Volcanoes. Academic Press, California, pp. 643-662.

Llambías, E.J., 1966. Geología y petrología del volcán Payún Matrú. Acta Geol. Lilloana 8 , 265-315.

Llambías, E.J., Bertotto, G.W., Risso, C., Hernando, I.R., 2010. El volcanismo cuaternario en el retroarco de Payenia: una revisión. Rev. Asoc. Geol. Argent. 67 (2), 278-300.

Lofgren, G., 1974. An experimental study of plagioclase crystal morphology: isotermal crystallization. Am. J. Sci. 274, 243-273.

Mandeville, C.W., Carey, S., Sigurdsson, H., 1996. Magma mixing, fractional crystallization and volatile degassing during the 1883 eruption of Krakatau volcano, Indonesia. J. Volcanol. Geotherm. Res. 74, 243-274.

Marchetti, D.W., Hynek, S.A., Cerling, T.E., 2014. Cosmogenic ${ }^{3}$ He exposure ages of basalt flows in the northwestern Payún Matrú volcanic field, Mendoza province, Argentina. Quat. Geochronol. 19, 67-75.

Mazzoni, M.M., Licitra, D.T., 2000. Significado estratigráfico y volcanológico de depósitos de flujos piroclásticos neógenos con composición intermedia en la zona del lago Caviahue, provincia del Neuquén. Rev. Asoc. Geol. Argent. 55 (3), 188-200.

Murphy, M.D., Sparks, R.S.J., Barclay, J., Carroll, M.R., Brewer, T.S., 2000. Removilization of andesite magma by intrusion of mafic magma alt the Soufriere Hills volcano, Montserrat, West Indies. J. Petrol. 41, 21-42.

Nakamura, M., Shimakita, S., 1998. Dissolution origin and syn-entrapment compositiona change of melt inclusion in plagioclase. Earth Planet. Sci. Lett. 161, 119-133.

Nelson, S.T., Montana, A., 1992. Sieve-textured plagioclase in volcanic rocks produced by rapid decompression. Am. Mineral. 77, 1242-1249.

Pallister, J.S., Hoblitt, R.P., Reyes, A.G., 1992. A basalt trigger for the 1991 eruptions of Pinatubo volcano? Nature 356, 426-428.

Patiño Douce, A.E., 1993. Titanium substitution in biotite: an empirical model with applications to thermometry, $\mathrm{O}_{2}$ and $\mathrm{H}_{2} \mathrm{O}$ barometries, and consequences for biotite stability. Geochem. Geol. 108, 133-162.

Petrinovic, I.A., Martí, J., Aguirre-Díaz, G.J., Guzmán, S., Geyer, A., Salado Paz, N., 2010. The Cerro Aguas Calientes caldera, NW Argentina: an example of a tectonically controlled polygenetic collapse caldera, and its regional significance. J. Volcanol. Geotherm. Res. 194, 15-26.

Putirka, K., 2005. Igneous thermometers and barometers based on plagioclase + liquid equilibria: tests of some existing models and new calibrations. Am. Mineral. 90, 336-346.

Putirka, K.D., 2008. Thermometers and barometers for volcanic systems. Rev. Mineral. Geochem. 69 (1), 61-120.

Putirka, K., Johnson, M., Kinzler, R., Longhi, J., Walker, D., 1996. Thermobarometry of mafic igneous rocks based on clinopyroxene-liquid equilibria, 0-30 kbar. Contrib. Mineral. Petrol. 123, 92-108.

Putirka, K.D., Mikaelian, H., Ryerson, F., Shaw, H., 2003. New clinopyroxene-liquid thermobarometers for mafic, evolved, and volatile-bearing lava compositions, with applications to lavas from Tibet and the Snake River Plain, Idaho. Am. Mineral. 88, 1542-1554.

Putirka, K., Perfit, M., Ryerson, F.J., Jackson, M.G., 2007. Ambient and excess mantle temperatures, olivine thermometry, and active vs. passive upwelling. Chem. Geol. 241, 177-206.

Quidelleur, X., Carlut, J., Tchilinguirian, P., Germa, A., Gillot, P.-Y., 2009. Paleomagnetic directions from mid-latitude sites in the southern hemisphere (Argentina): contribution to time averaged field models. Phys. Earth Planet. Inter. 172, 199-209.

Reguzzoni, M., Sampietro, D., Sansò, F., 2013. Global Moho from the combination of the CRUST2.0 model and GOCE data. Geophys. J. Int. http://dx.doi.org/10.1093/gji/ ggt247.

Riller, U., Petrinovic, I., Ramelow, J., Strecker, M., Oncken, O., 2001. Late Cenozoic tectonism, collapse caldera and plateau formation in the central Andes. Earth Planet. Sci. Lett. 188, 299-311.

Roeder, P.L., Emslie, R.F., 1970. Olivine-liquid equilibrium. Contrib. Mineral. Petrol. 29, 275-289.

Ruprecht, P., Bachmann, O., 2010. Pre-eruptive reheating during magma mixing at Quizapu volcano and the implications for the explosiveness of silicic arc volcanoes. Geology 38, 919-922. 
Rutherford, M.J., Hill, P.M., 1993. Magma ascent rates from amphibole breakdown: an experimental study applied to the 1980-1986 Mount St. Helens eruptions. J. Geophys. Res. 98 (11), 667-685.

Snyder, D., 2000. Thermal effects of the intrusion of basaltic magma into a more silicic magma chamber and implications for eruption triggering. Earth Planet. Sci. Lett. $175,257-273$.

Søager, N., Holm, P.M., Llambías, E.J., 2013. Payenia volcanic province, Southern Mendoza, Argentina: OIB mantle upwelling in a back-arc environment. Chem. Geol. 349-350, $36-53$.

Søager, N., Holm, P.M., Thirlwall, M.F., 2015. Sr, Nd, Pb, and Hf isotopic constraints on mantle sources and crustal contaminants in the Payenia volcanic province, Argentina. Lithos 212-215, 368-378.

Sparks, R.S.J., Marshall, L.A., 1986. Thermal and mechanical constraints on mixing between mafic and silicic magmas. J. Volcanol. Geotherm. Res. 29, 99-124.

Sruoga, P. Etcheverría, M.P. Feineman, M., Rosas, M., Burkert, C., Ibañes, O., 2012. Complejo caldera Diamante - volcán Maipo ( $34^{\circ} 10^{\prime} \mathrm{S}, 69^{\circ} 50^{\prime}$ O): Evolución volcanológica y geoquímica e implicancias en su peligrosidad. Rev. Asoc. Geol. Argent. 69 (4), 508-530.
Stimac, J.A., Pearce, T.H., 1992. Textural evidence of mafic-felsic magma interaction in dacite lavas, Clear Lake, California. Am. Mineral. 77, 795-809.

Tsuchiyama, A., 1985. Dissolution kinetics of plagioclase in the melt of the system diopside-albite-anorthite, and origin of dusty plagioclase in andesites. Contrib. Mineral. Petrol. 89, 1-16.

Turner, J.S., Campbell, I.H., 1986. Convection and mixing in magma chambers. Earth Sci. Rev. 23, 255-352.

Varekamp, J.C. Maarten de Moor, J., Merrill, M.D. Colvin, A.S, Goss, A.R., Vroon, P.Z Hilton, D.R., 2006. Geochemistry and isotopic characteristics of the CaviahueCopahue volcanic complex, province of Neuquén, Argentina. Geol. Soc. Am. Spec. Pap. 407, 317-342.

Vernon, R.H., 2004. A Practical Guide to Rock Microstructure. Cambridge University Press, New York.

Wagner, L.S., Beck, S., Zandt, G., 2005. Upper mantle structure in the south central Chilean subduction zone $\left(30^{\circ}\right.$ to $\left.36^{\circ} \mathrm{S}\right)$. J. Geophys. Res. $110, \mathrm{~B} 01308$.

Yuan, X., Asch, G., Bataille, K., Bock, G., Bohm, N., 2006. Deep seismic images of the Southern Andes. Geol. Soc. Am. Spec. Pap. 407, 61-72. 